\title{
Organic acids for performance enhancement in pig diets
}

\author{
Kirsi H. Partanen* and Zdzislaw Mroz \\ Institute for Animal Science and Health (ID-DLO), Department of Nutrition of Pigs and Poultry, \\ PO Box 65, 8200 AB Lelystad, The Netherlands
}

\begin{abstract}
Organic acids and their salts appear to be potential alternatives to prophylactic in-feed antibiotics and growth promoters in order to improve the performance of weaned piglets, fattening pigs and reproductive sows, although their growth-promoting effects are generally less than that of antibiotics. Based on an analysis of published data, the growth-promoting effect of formates, fumarates and citrates did not differ in weaned piglets. In fattening pigs, formates were the most effective followed by fumarates, whereas propionates did not improve growth performance. These acids improved the feed: gain ratio of both weaned piglets and fattening pigs. In weaned piglets, the growth-promoting effects of dietary organic acids appear to depend greatly on their influence on feed intake. In sows, organic acids may have anti-agalactia properties. Successful application of organic acids in the diets for pigs requires an understanding of their modes of action. It is generally considered that dietary organic acids or their salts lower gastric $\mathrm{pH}$, resulting in increased activity of proteolytic enzymes and gastric retention time, and thus improved protein digestion. Reduced gastric $\mathrm{pH}$ and increased retention time have been difficult to demonstrate, whereas improved apparent ileal digestibilities of protein and amino acids have been observed with growing pigs, but not in weaned piglets. Organic acids may influence mucosal morphology, as well as stimulate pancreatic secretions, and they also serve as substrates in intermediary metabolism. These may further contribute to improved digestion, absorption and retention of many dietary nutrients. Organic acid supplementation reduces dietary buffering capacity, which is expected to slow down the proliferation and/or colonization of undesirable microbes, e.g. Escherichia coli, in the gastro-ileal region. However, reduced scouring has been observed in only a few studies. As performance responses to dietary organic acids in pigs often varies, more specific studies are necessary to elucidate an explanation.
\end{abstract}

Performance enhancers: Organic acids: Growth

\section{Introduction}

Intensification of pig farming has led to shortening of the suckling period of piglets from 5-6 to 3-4 weeks of age in order to maximize annual sow productivity. A side effect of this is a higher

Abbreviations: AID, apparent ileal digestion; ATTD, apparent total tract digestibility; BW, body weight; CP, crude protein; VFA, volatile fatty acid.

* Corresponding author: current address Agricultural Research Centre of Finland, Animal Production Research, 31600 Jokioinen, Finland, fax +358 3418 83661, email kirsi.partanen@mtt.fi 
risk of postweaning diarrhoea, which causes retarded growth, increased mortality and extra medication costs (Jahn \& Uecker, 1987; Aumaître et al. 1995). Digestive disorders and consequent poor performance can also be a problem in the fattening phase, i.e. when pigs from different rearing compartments or farms are transported, mixed in a fattening unit and changed on to a new diet. In order to prevent diarrhoea and to improve performance, prophylactic doses of antimicrobial feed additives, i.e. antibiotics or antibiotic-like growth promoters, are commonly applied in weaner and grower diets. In recent years, however, public concern over development of resistant pathogen strains and antibiotic residues in animal products has led to pressure to search for alternative means of controlling scours with no hazard for consumers. In this context, organic acids which are natural constituents of some feeds, and occur in body metabolism and the gastrointestinal tract, are attractive alternatives, as they may constitute a prophylactic and growth-promoting measure similar to that provided by antimicrobial feed additives.

Weaning at 3-4 weeks of age exposes piglets to both nutritional and environmental stress, which often results in reduced feed intake, little or no weight gain, and in some instances diarrhoea, morbidity and death. This postweaning lag period is a result of a limited digestive and absorptive capacity due to insufficient production of $\mathrm{HCl}$, pancreatic enzymes and sudden changes in feed consistency and intake (Aumaître et al. 1995; Cranwell, 1995). At this age the immunological status of a piglet is also low as passive immunity acquired through maternal colostrum is dramatically decreased, and active immunity is only beginning to develop (Gaskin \& Kelley, 1995). Lowering dietary $\mathrm{pH}$ by weak organic acids, such as citric, formic, fumaric, lactic or propionic acid has been reported to be helpful in overcoming problems of the postweaning lag period (Falkowski \& Aherne, 1984; Henry et al. 1985).

Although the organic acid supplementation was initially targeted for weaned piglets, there is growing evidence that dietary acidification may also be beneficial for the performance of fattening pigs. Recent results have indicated that in fattening pigs organic acids improved the apparent ileal digestibility of protein and amino acids (Mosenthin et al. 1992; Kemme et al. 1995; Mroz et al. 1997) and absorption of minerals (Jongbloed \& Jongbloed, 1996). This may contribute not only to improved performance but also to reduced $\mathrm{N}$ and $\mathrm{P}$ excretion. In recent years, pig husbandry worldwide has been under increasing pressure to develop feasible solutions to improve the efficiency of $\mathrm{N}$ and $\mathrm{P}$ utilization and to decrease their excretion. Dietary acidification may be an option to get closer to this target. Organic acids are also known as effective preservatives which protect stored feeds against undesirable bacterial or fungal growth (Frank, 1994), and improved quality of feeds over time may further contribute to improved performance.

The aim of this review is to evaluate the response of weaned piglets, growing pigs and reproductive sows to dietary organic acids as illustrated in terms of performance, i.e. growth rate, feed intake and feed utilization. In addition, reasons for varying responses to and possible modes of action of organic acids will be discussed. A brief summary of the properties of particular organic acids will be given at the beginning of this review.

\section{Properties, absorption and metabolism of organic acids}

Organic acids $(\mathrm{C} 1-\mathrm{C} 7)$ are widely distributed in nature as normal constituents of plants or animal tissue. They are also formed through microbial fermentation of carbohydrates predominantly in the large intestine of pigs. Some physical and chemical properties of organic acids that are used as acidifiers in pig diets are presented in Table 1. Many of them are also available as sodium, potassium or calcium salts. The advantage of salts over free acids is that 
Table 1. Formulas, physical and chemical characteristics of organic acids used as dietary acidifiers for pigs (Foegeding \& Busta, 1991)

\begin{tabular}{|c|c|c|c|c|c|c|}
\hline Acid & Formula & $\begin{array}{c}\mathrm{MM} \\
(\mathrm{g} / \mathrm{mol})\end{array}$ & $\begin{array}{l}\text { Density } \\
\text { (g/ml) }\end{array}$ & Form & $\mathrm{pK}_{\mathrm{a}}$ & $\begin{array}{l}\text { Solubility } \\
\text { in water }\end{array}$ \\
\hline Formic & $\mathrm{HCOOH}$ & 46.03 & 1.220 & liquid & 3.75 & $\infty$ \\
\hline Acetic & $\mathrm{CH}_{3} \mathrm{COOH}$ & 60.05 & 1.049 & liquid & 4.76 & $\infty$ \\
\hline Propionic & $\mathrm{CH}_{3} \mathrm{CH}_{2} \mathrm{COOH}$ & 74.08 & 0.993 & liquid & 4.88 & $\infty$ \\
\hline Butyric & $\mathrm{CH}_{3} \mathrm{CH}_{2} \mathrm{CH}_{2} \mathrm{COOH}$ & $88 \cdot 12$ & 0.958 & liquid & 4.82 & $\infty$ \\
\hline Lactic & $\mathrm{CH}_{3} \mathrm{CH}(\mathrm{OH}) \mathrm{COOH}$ & 90.08 & 1.206 & liquid & 3.83 & $v$ \\
\hline Sorbic & $\mathrm{CH}_{3} \mathrm{CH}: \mathrm{CHCH}: \mathrm{CHCOOH}$ & $112 \cdot 14$ & 1.204 & solid & 4.76 & $s$ \\
\hline Fumaric & $\mathrm{COOHCH}: \mathrm{CHCOOH}$ & $116 \cdot 07$ & 1.635 & solid & $\begin{array}{l}3.02 \\
4.38\end{array}$ & $s$ \\
\hline Malic & $\mathrm{COOHCH}_{2} \mathrm{CH}(\mathrm{OH}) \mathrm{COOH}$ & 134.09 & & liquid & $\begin{array}{l}3 \cdot 4 \\
5 \cdot 1\end{array}$ & $\infty$ \\
\hline Tartaric & $\mathrm{COOHCH}(\mathrm{OH}) \mathrm{CH}(\mathrm{OH}) \mathrm{COOH}$ & $150 \cdot 09$ & 1.760 & liquid & $\begin{array}{l}2.93 \\
4.23\end{array}$ & $v$ \\
\hline Citric & $\mathrm{COOHCH}_{2} \mathrm{C}(\mathrm{OH})(\mathrm{COOH}) \mathrm{CH}_{2} \mathrm{COOH}$ & $192 \cdot 14$ & 1.665 & solid & $\begin{array}{l}3.13 \\
4.76 \\
6.40\end{array}$ & $v$ \\
\hline
\end{tabular}

$\mathrm{MM}$, molecular mass expressed in grams.

$\infty$, soluble in all proportions; $v$, very soluble; $s$, sparingly soluble.

they are generally odourless and easier to handle in the feed manufacturing process owing to their solid and less volatile form. They are also less corrosive and may be more soluble in water than the free acids.

Rather than dietary acidifiers, organic acids are better known as effective preservatives. Their primary antimicrobial action (strain-selective growth inhibition or delay) is through $\mathrm{pH}$ depression of the diet. However, more importantly the ability of organic acids to change from undissociated to dissociated form, depending on the environmental $\mathrm{pH}$, makes them effective antimicrobial agents. When acid is in the undissociated form it can freely diffuse through the semipermeable membrane of micro-organisms into their cell cytoplasm. Once inside the cell, where the $\mathrm{pH}$ is maintained near 7, the acid will dissociate and suppress cell enzymes (decarboxylases and catalases) and nutrient transport systems (Lueck, 1980). The efficacy of an acid in inhibiting microbes is dependent on its $\mathrm{pK}_{\mathrm{a}}$ value which is the $\mathrm{pH}$ at which $50 \%$ of the acid is dissociated. Organic acids with higher $\mathrm{pK}_{\mathrm{a}}$ values are more effective preservatives and their antimicrobial efficacy is generally improved with increasing chain length and degree of unsaturation (Foegeding \& Busta, 1991).

\section{Formic acid}

Formic acid is a colourless, transparent liquid with a pungent odour. It is commonly used as a preservative in ensiling forage and various by-products which contain less substrate for the desirable production of lactic acid by lactobacilli. Formate is a natural constituent of animal tissue and blood. It is metabolically important in the transfer of 1-C intermediary substances which are generated primarily during amino acid metabolism, and serves as a substrate for biosynthesis of purine bases and thus nucleic acids (Stryer, 1988). Accumulation of formate in the body causes the toxic symptoms of methanol poisoning, i.e. metabolic acidosis, ocular 
pathological changes and death (Tephly, 1991). Acute toxicity $\left(\mathrm{LD}_{50}\right)$ after oral application of formic acid is $1-2 \mathrm{~g} / \mathrm{kg}$ body weight (BW; Lueck, 1980). Sodium and potassium formates are less acutely toxic.

Ingested formic acid is readily absorbed through mucous membranes. In undissociated form it can rapidly diffuse across the cell membrane. The absorption mechanism is similar to that of other short-chain fatty acids (Chang \& Rao, 1994). Most of the absorbed formic acid is transported to the liver where it enters the body's 1-C pool and is oxidized to $\mathrm{CO}_{2}$ and $\mathrm{H}_{2} \mathrm{O}$. The remaining portion can be excreted as its alkaline salts (formates) via the kidneys. The first stage that formate goes through while entering the 1-C pool of the body is to combine with tetrahydrofolic acid to form 10-formyltetrahydrofolate in a reaction catalysed by 10 -formyltetrahydrofolate synthetase (EC 6.3.4.3). The 10-formyltetrahydrofolate is then oxidized to $\mathrm{CO}_{2}$, a process mediated by 10-formyltetrahydrofolate dehydrogenase (EC 1.5.1.6) (Johlin et al. 1987, 1989). The rate of formate oxidation depends on the hepatic folic acid level, particularly that of tetrahydrofolate. Pigs have extremely low hepatic folate levels and very low levels of 10-formyltetrahydrofolate dehydrogenase, a key enzyme in the folate pathway, and thus their ability to metabolize formate is limited (Johlin et al. 1987; Makar et al. 1990). However, hepatic folate reserves in pigs can be effectively increased by dietary folate supplementation (Letendre et al. 1991). It has been shown with mink that the rate of formate oxidation is increased when diets are supplemented with folic acid (Pölönen et al. 1997).

Formic acid is an effective acidulant, but it can also inhibit microbial decarboxylases and enzymes such as catalases. Overall, the antimicrobial activity of formic acid is primarily against yeasts and some bacteria, whereas lactic acid bacteria and moulds are relatively resistant to its effects (Lueck, 1980). Formic acid is effective in small concentrations (21.7 mM) against $E$. coli. In addition, formic acid treatment can effectively eliminate salmonella from contaminated feeds (Frank, 1994).

\section{Acetic, propionic and butyric acids}

Acetic acid is a colourless liquid with a pungent odour. It is produced through oxidation of alcohol by Acetobacter bacteria. Propionic and $n$-butyric acids are both oily liquids and have disagreeable rancid odours. Propionic acid is produced by Propionibacterium in the manufacture of cheese (Foegeding \& Busta, 1991). It also arises as a metabolite in the degradation of valine (Stryer, 1988). Acetic, propionic and butyric acids are the major end products of bacterial fermentation of dietary fibre in the colon of the pig and they are absorbed by passive diffusion (Kidder \& Manners, 1978). Absorption rate depends greatly upon the $\mathrm{pK}_{\mathrm{a}}$ and the luminal $\mathrm{pH}$. When the luminal $\mathrm{pH}$ is below the $\mathrm{pK}_{\mathrm{a}}$, short-chain fatty acids are absorbed very rapidly. Because the luminal $\mathrm{pH}$ in ileum, caecum and colon of the pig is generally greater than 6.5 , most short-chain fatty acids remain in their dissociated form and are poorly absorbed. However, $\mathrm{Na}-\mathrm{H}$ ion exchange by the epithelial cells may decrease the local $\mathrm{pH}$ at the absorptive surface, leading to a shift from the ionic to the free acid state, and the absorption proceeds because of a concentration gradient between the lumen and epithelial cells (Chang \& Rao, 1994).

Absorbed acetate and butyrate, including those formed in the intermediary metabolism, enter the citric-acid cycle after being converted to acetyl-CoA. The major metabolic route of propionate is to succinyl-CoA with methylmalonyl-CoA as an intermediate (Stryer, 1988). A small portion of propionate is converted to lactate by the epithelial cells which also appear to oxidize acetate completely (McDonald et al. 1995). 
As a preservative, acetic acid inhibits the growth of many species of bacteria, and to a lesser extent of yeasts and moulds. The action of propionic acid is primarily against moulds. It has only poor activity against bacteria and none against yeasts, since the latter can metabolize it (Foegeding \& Busta, 1991). The minimum concentration of acetic or propionic acid that prevents $E$. coli is $0.5 \%$, which is five times higher than that of formic acid (Frank, 1994).

\section{Lactic acid}

Lactic acid is produced by many bacterial species, primarily those of the genera Lactobacillus, Bifidobacterium, Streptococcus, Pediococcus and Leuconostoc. It is a natural constituent of some feedstuffs and is among the oldest of the preservatives. The antimicrobial action of lactic acid is directed primarily against bacteria, whereas many moulds and yeasts can metabolize it (Foegeding \& Busta, 1991).

In the stomach and small intestine, lactic acid is produced as an end product of sugar fermentation. Lactate is also produced by muscle cells from glycogen when the oxygen supply is inadequate to support pyruvate oxidation and ATP production via aerobic metabolism. The lactate entering the blood stream either from muscles or from the gastrointestinal lumen is carried to the liver where it is reoxidized to pyruvate. Pyruvate can then be oxidized via the citric-acid cycle (Stryer, 1988).

\section{Citric and fumaric acids}

Citric and fumaric acids are both crystalline and odourless. Citric acid has a pleasant sour taste and fumaric acid has a tart flavour. Citric acid is generally a less effective antimicrobial agent than other organic acids, partly because many micro-organisms can metabolize it and also because of a low $\mathrm{pK}_{\mathrm{a}}$ (Foegeding \& Busta, 1991).

Dietary fumarate and citrate are absorbed by a common $\mathrm{Na}^{+}$-gradient mechanism which is specific for tri- and dicarboxylates (Wolffram et al. 1990, 1992). In the pig, fumaric acid arises as a metabolite from the degradation of phenylalanine and tyrosine and also occurs as an intermediate in the urea cycle and during purine synthesis. Fumarate and citrate formed in the intermediary metabolism, as well as those of dietary origin, are directed to the citric-acid cycle where they serve as important intermediary metabolites (Stryer, 1988).

\section{Other acids}

A number of other organic acids, e.g. malic, tartaric and sorbic acids, and acid blends have also been studied as dietary acidifiers for pigs. Malic is naturally found in apples and many other fruits and is active against certain bacteria and yeasts. Tartaric acid, which is the primary acid of grapes, has a strong acid taste. Sorbic acid is present in certain berries and has a distinctive odour and sour taste; it is considered non-toxic and is metabolized via $\beta$ - and $\omega$-oxidation, as are the long-chain fatty acids. The $\mathrm{LD}_{50}$ for sorbic acid is in the range $7-11 \mathrm{~g} / \mathrm{kg} \mathrm{BW}$. Sorbic acid inhibits yeasts, moulds and some bacteria. Its antimicrobial action is due to the inhibition of enzymes and nutrient transport (Foegeding \& Busta, 1991). 


\section{Organic acids and pig performance}

To evaluate the effects of dietary organic acids on performance (average daily gain, feed intake and feed:gain ratio) of weaned piglets and fattening pigs, data were collected from the literature and subjected to a meta-analysis (Hedges \& Olkin, 1985). Studies in which the following criteria were reported were chosen for the analysis: initial and final weight of pigs, average daily gain, feed intake, feed:gain ratio and their standard deviations, number of observations per treatment, diet composition (simple or complex, with or without dairy products) and feed allowance (ad lib. or restricted). Dietary organic acid levels $(\mathrm{g} / \mathrm{kg}$ ) were converted to milliequivalents (mequiv./kg) to make the levels of different acids more comparable.

Experimental diets which contained other growth promoters, e.g. antimicrobial feed additives, $\mathrm{Cu}$ or probiotics, in addition to organic acids, were excluded from the data. Acid blends were also excluded from the data, since their composition was seldom reported and it was impossible to calculate accurate acid levels as milliequivalents.

The unbiased effect size (response) $d$ was calculated on the basis of the standardized mean difference adjusted for sample size (Hedges \& Olkin, 1985) as follows:

$$
d \cong(1-3 /(4 N-9))\left(Y^{\mathrm{E}}-Y^{\mathrm{C}}\right) / s,
$$

where $N$ is the total sample size, $Y^{\mathrm{E}}$ and $Y^{\mathrm{C}}$ are the respective experimental and control group means and $s$ is their pooled standard deviation. Positive values indicate an increase and negative values a decrease in performance response. The effect size data were analysed by the procedure for mixed models by SAS (Littell et al. 1996). The final models used to describe the response in growth and feed : gain ratio were chosen on the basis of log likelihood ratios (Table 2 ). For weaned piglets the models for both growth and feed: gain ratio response included the effects of acid, dietary acid level, feed intake (unbiased effect size) and acid $\times$ feed intake interaction (model 3), and for fattening pigs the effects of acid and acid level (model 2).

Table 2. Selection of models used for the meta-analysis of published data

\begin{tabular}{|c|c|c|c|c|c|c|c|c|c|c|}
\hline Model & Acid & Level & $\begin{array}{c}\text { Acid } \times \\
\text { level }\end{array}$ & Level $^{2}$ & $\begin{array}{r}\text { Acid } \times \\
\text { level }^{2}\end{array}$ & $\begin{array}{c}\text { Feed } \\
\text { intake }\end{array}$ & $\begin{array}{c}\text { Acid } \times \\
\text { feed } \\
\text { intake }\end{array}$ & $\begin{array}{c}-2 \text { log } \\
\text { likelihood }\end{array}$ & df & $P$ \\
\hline \multicolumn{11}{|c|}{ Weaned piglets } \\
\hline 1 & $x$ & $x$ & $x$ & $x$ & $x$ & $x$ & $x$ & -6.0322 & 26 & \\
\hline 2 & $x$ & $x$ & $x$ & & & $x$ & $x$ & 0.5116 & 29 & 0.088 \\
\hline 3 & $x$ & $x$ & & & & $x$ & $x$ & $3 \cdot 2244$ & 31 & 0.258 \\
\hline \multicolumn{11}{|c|}{ Feed to gain } \\
\hline 1 & $x$ & $x$ & $x$ & $x$ & $x$ & $x$ & $x$ & $119 \cdot 1687$ & 20 & \\
\hline 2 & $x$ & $x$ & $x$ & & & $x$ & $x$ & 115.4194 & 22 & 0.153 \\
\hline 3 & $x$ & $x$ & & & & $x$ & $x$ & $115 \cdot 9182$ & 24 & 0.779 \\
\hline \multicolumn{11}{|c|}{ Fattening pigs } \\
\hline \multicolumn{11}{|c|}{ Average daily gain } \\
\hline 1 & $x$ & $x$ & $x$ & & & & & $22 \cdot 0198$ & 14 & \\
\hline 2 & $x$ & $x$ & & & & & & $24 \cdot 3769$ & 16 & 0.502 \\
\hline \multicolumn{11}{|c|}{ Feed to gain } \\
\hline 1 & $x$ & $x$ & $x$ & & & & & $18 \cdot 1295$ & 14 & \\
\hline 2 & $\mathrm{x}$ & $\mathrm{x}$ & & & & & & $19 \cdot 6458$ & 16 & 0.471 \\
\hline
\end{tabular}

df, degrees of freedom.

$P$, probability that the model differs from the preceding model. 


\section{Weaned piglets}

Fumaric and citric-acids are the most commonly studied organic acids in weaner diets. Recently, an increasing interest has been directed towards formic acid and its calcium, sodium or potassium salts. In general, dietary organic acids seem to improve the growth performance and feed: gain ratio of weaned piglets (Fig. 1; Table 3) but the responses vary greatly, ranging from $-58 \mathrm{~g} / \mathrm{d}$ (BW losses) up to $+106 \mathrm{~g} / \mathrm{d}$ (BW gain). Potential reasons for the varying results may relate to differences in the type and dose of acid used, composition of basal diet, age of animals, and existing levels of performance (Ravindran \& Kornegay, 1993).

Type and level of acid. On average, formic acid or formates, fumaric acid and citric-acid improved the average daily gain of weaned piglets and reduced the feed : gain ratio relative to the non-acidified control diet (Table 3$)$. In the range of acid levels studied $(<450$ mequiv. $/ \mathrm{kg})$, growth response increased $(b=0.0087$ (SD 0.0003), $P<0.01)$ and feed: gain ratio decreased $(b=-0.0040$ (SD 0.0010), $P<0.001$ ) slightly with increasing dietary acid level. From these data it was not possible to find an optimal level of dietary organic acid. Differences between the acids studied (formic acid or formates, fumaric acid and citric-acid) were not significant. Other acids, e.g. acetic (Roth \& Kirchgessner, 1988), lactic (Schulz \& Fischer, 1983; Roth et al. 1993) and sorbic acid (Kirchgessner et al. 1995), have also shown growth-promoting effects, but the number of experiments was too small to be included in the meta-analysis. The growthpromoting effects of dietary organic acids appear to be smaller than those of antibiotics or antibiotic-like growth promoters. Organic acids can also enhance the effects of antibiotics by improving their absorption (Petersen \& Oslage, 1982b; Edmonds et al. 1985; Radecki et al. 1988; Eidelsburger et al. 1992b).

The growth and feed: gain responses of weaned piglets to dietary organic acids were best explained when the changes in feed intake were included in the model, since performance responses were closely related to changes in feed intake (Fig. 2). However, with the information available from the literature it was not possible to find a satisfactory model to explain the effects of dietary organic acids on feed intake. Previously improved growth of piglets fed on acidified diets has been ascribed to a better diet palatability (Cole et al. 1968; Bolduan et al. $1988 a, b)$. The literature data indicate that different organic acids may have different effects on feed intake: in general, dietary formic acid or formates had a positive effect, fumaric acid had no effect and citric-acid had a negative effect. These effects may also be related to the age of the piglets, younger piglets being more sensitive to the changes in diet palatability. Although the growth-promoting effects of dietary organic acids appear to depend greatly on how they improve feed intake, so far hardly any attention has been paid to the influence of organic acids on the palatability of prestarter or starter diets. In the study of Henry et al. (1985), when free access was allowed to both acidified and non-acidified (citric and fumaric acids) diets, pigs consumed significantly more of the non-acidified diet.

Certain acids, e.g. tartaric and formic acids, have a strong odour and flavour, and an increasing dietary acid level is generally associated with a dramatic decrease in feed intake, as reflected by lower daily gains (Eckel et al. 1992a; Kirchgessner et al. 1993). Addition of excessive amounts of formates to the diet may also disturb the acid-base status of pigs leading to metabolic acidosis, which results in decreased feed intake and slower growth (Giesting et al. 1991; Eckel et al. 1992a; Eidelsburger et al. 1992e; Grassmann et al. 1992). Organic acids metabolized via the citric-acid cycle, e.g. fumaric and citric-acids, do not seem to cause acidosis, irrespective of their dietary inclusion (Eidelsburger et al. 1992c). 
(a)

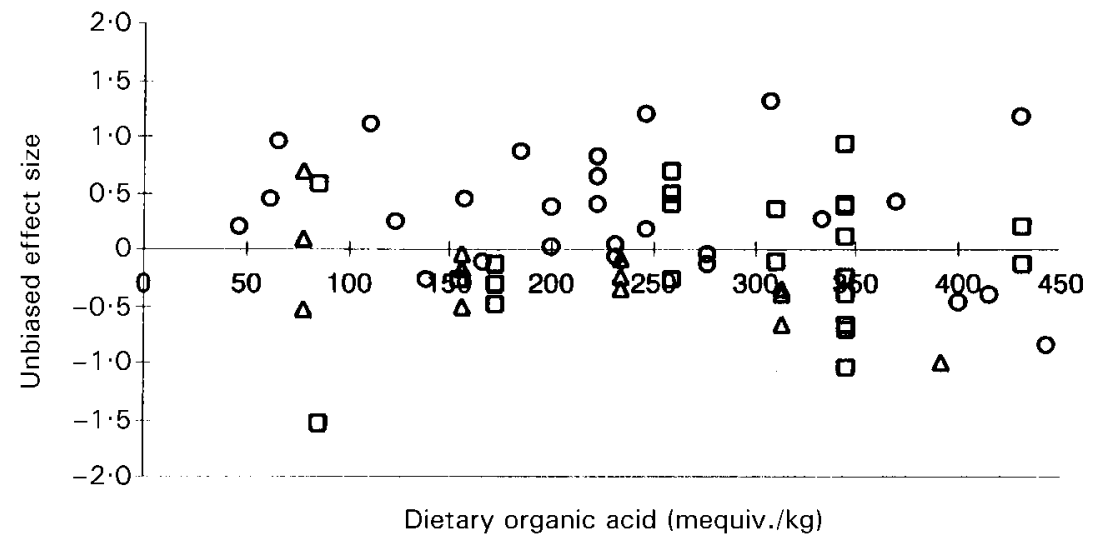

(b)

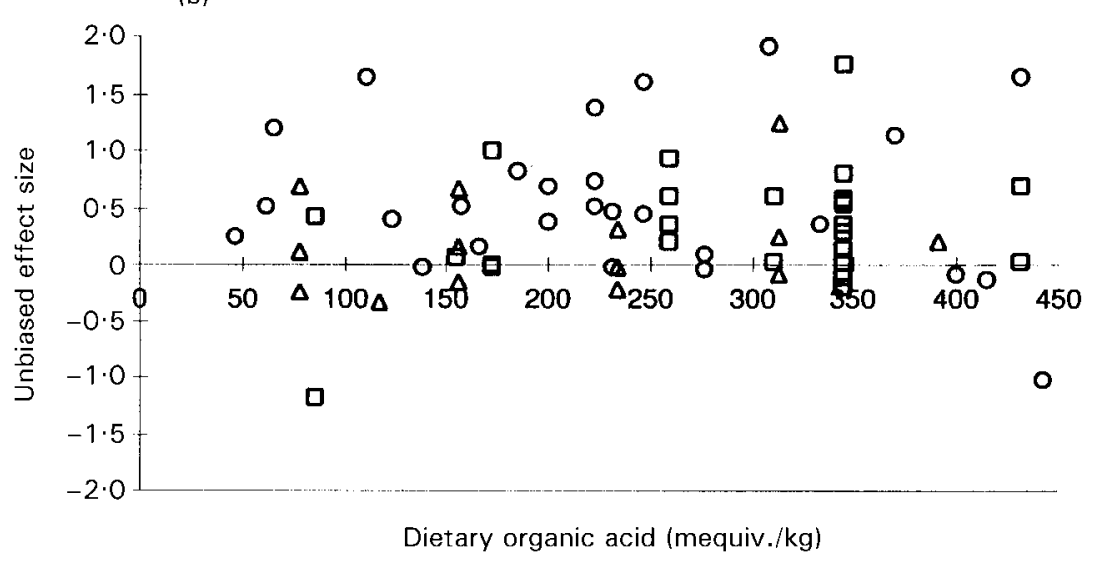

(c)

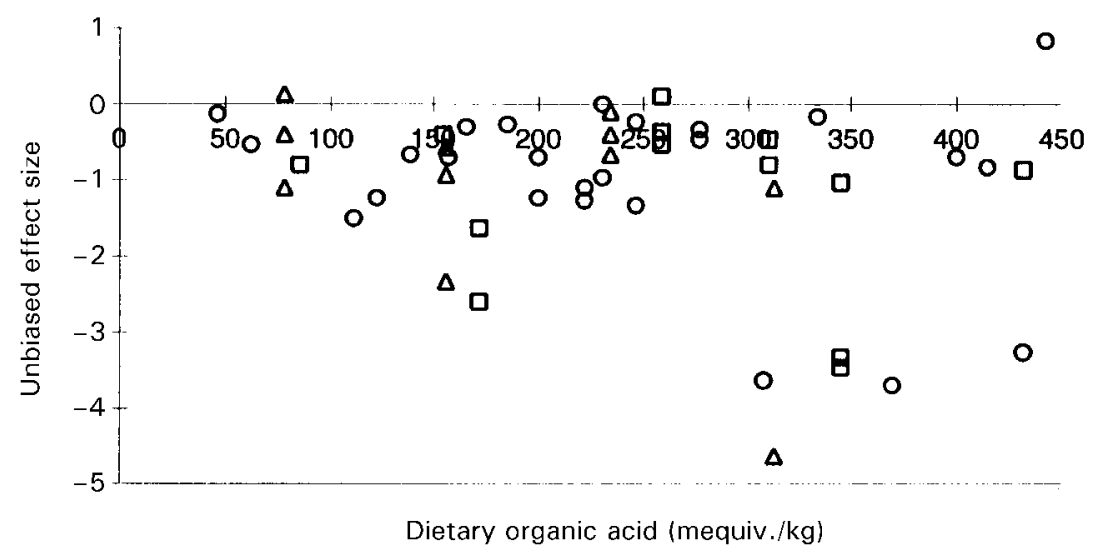

Fig. 1. The effect of dietary formic acid or formates $(\bigcirc)$, fumaric acid $(\square)$ and citric acid $(\triangle)$ on (a) feed intake, (b) average daily BW gain and (c) feed: gain ratio of weaned piglets relative to nonacidified control diets. 


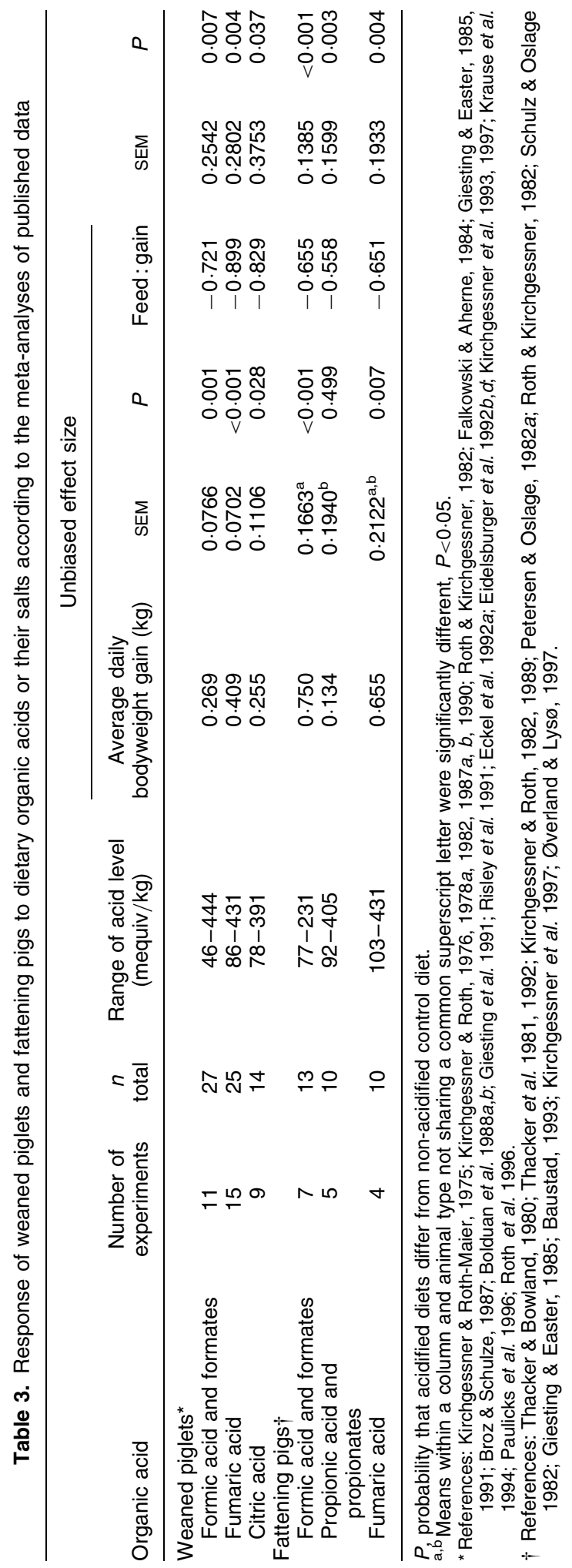




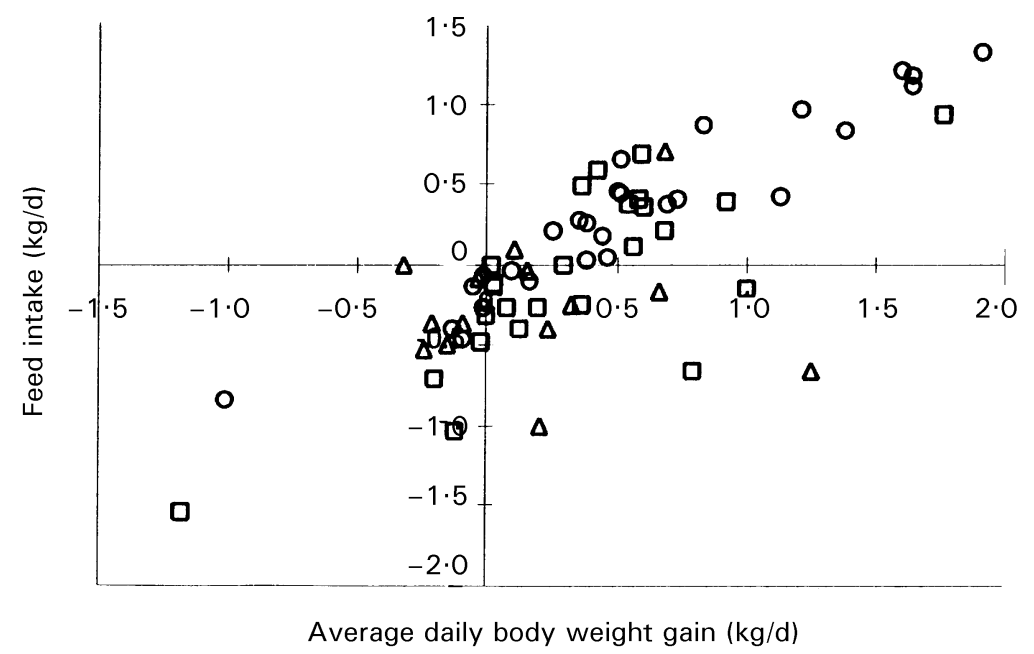

Fig. 2. The relationship between feed intake and growth response (unbiased effect size) of weaned piglets to dietary formic acid or formate $(\bigcirc)$, fumaric acid $(\square)$ and citric acids $(\triangle)$ supplementation.

Type of diet. The literature data did not allow the effect of diet type (simple or complex, with or without dairy products) on the growth-promoting effects of dietary organic acids to be differentiated, as diet type was often confounded with the age of piglet, i.e. prestarter diets generally contained milk products whereas weaner diets were without them. However, a few studies indicate that the response of weaned piglets to organic acids may depend on ingredient and chemical composition of the diet. The greatest acidification benefits have been observed when diets were formulated from cereals and plant proteins, while the growth-promoting effect was small in diets containing milk products (Burnell et al. 1988; Giesting et al. 1991; Weeden et al. 1991; Roth et al. 1993). The latter presumably holds true when lactose in milk products is converted to lactic acid by lactobacilli in the stomach, creating the desired reduction in $\mathrm{pH}$ and thus reducing the need for diet acidification (Easter, 1988).

The observed differences in performance responses to dietary organic acids may also be due to differences in dietary buffering capacity (Bolduan et al. 1988a,b). The buffering capacity varies substantially between different feedstuffs. The acid-buffering capacity is lowest in cereals and cereal by-products, intermediate or high in protein feedstuffs and very high in mineral sources, except in dicalcium and monosodium phosphates (Jasaitis et al. 1987). Also the shape of titration curves varies greatly between feedstuffs (Wohlt et al. 1987). Addition of organic acids reduces dietary $\mathrm{pH}$ curvilinearly depending on the acid $\mathrm{pK}_{\mathrm{a}}$ value and buffering capacity of the diet. The $\mathrm{pH}$-lowering effect of different organic acids is reduced in the following order: tartaric acid $>$ citric-acid $>$ malic acid $>$ fumaric acid $>$ lactic and formic acids $>$ acetic acid $>$ propionic acid. Organic salts have only a small influence on dietary $\mathrm{pH}$. Addition of protein and mineral sources to the diet weakens the pH-lowering effect of the acid (Roth \& Kirchgessner, 1989a). It seems reasonable to assume that the buffering capacity of a pig feed can be considerably influenced by selection of feed ingredients, and it may in part reflect on differences in the effectiveness of acidifiers. In general, organic acids lower dietary buffering capacity, whereas certain organic salts can increase it. However, Roth \& Kirch- 
gessner (1989) found no direct relationship between piglet performance and reduction in dietary buffering capacity.

Weaning age and existing level of performance. Organic acid supplementation appears to be most effective during the first 2-4 weeks after weaning, and the effect declines as the pig matures (Giesting et al. 1991). Ravindran \& Kornegay (1993) suggested that a better performance could be expected in conditions which are suboptimal for growth of piglets. However, Risley et al. (1993) failed to observe any measurable effect of supplementation of $15 \mathrm{~g}$ citric or fumaric acid $/ \mathrm{kg}$ diet on postweaning growth performance or scouring when piglets were challenged with enterotoxigenic $E$. coli. Based on published data, the existing level of performance (average daily gain of control group) did not seem to influence performance responses to dietary organic acids.

\section{Fattening pigs and sows}

A summary of the literature data concerning changes in average daily gain and feed: gain ratio of fattening pigs relative to different levels of dietary organic acids is presented in Fig. 3 and Table 3. The dietary acid level range was limited to $<450$ mequiv. $/ \mathrm{kg}$. With higher levels of propionates a reduction in average daily BW gain has been observed as a result of decreased feed intake (Thacker \& Bowland, 1980, 1981; Thacker et al. 1981; 1992), possibly due to the strong odour and flavour of propionates. In the range of acid levels studied, the responses ranged from $-50 \mathrm{~g} / \mathrm{d}$ (BW losses) to $+58 \mathrm{~g} / \mathrm{d}$ (BW gain). Formic acid or formates were the most effective, followed by fumaric acid. The effect of propionates did not differ from zero. All these acids improved the feed: gain ratio of fattening pigs, but differences between the acids were not significant. Other organic acids or their salts, e.g. lactic acid, sodium butyrate, have also been shown to be effective growth promoters in fattening pigs (Gálfi \& Bokori, 1990; Jongbloed \& Jongbloed, 1996).

Feeding regimen (ad lib. or restricted) did not seem to influence the growth-promoting effects of organic acids, although the highest responses have been observed when the pigs have had $a d$ lib. access to feed. In general, the performance response of growing pigs to organic acids and their salts seems to be more consistent than that of weaned piglets. The response was somewhat higher in the grower than finisher phase (Kirchgessner \& Roth, 1978a, 1989; Kirchgessner et al. 1997). There were too few data to draw conclusions about the effect of diet type on the efficacy of dietary organic acids, but it seems that the largest benefits have been observed with complex by-product-based diets.

The effects of formic acid $(10 \mathrm{~g} / \mathrm{kg}$ diet $)$ for pregnant and lactating sows on performance and some agalactia-related criteria were presented by Mroz et al. (1998). The authors concluded that body mass changes over the whole cycle (pregnancy+lactation) were not influenced by formic acid, whereas the total feed intake during pregnancy was up to $7.7 \mathrm{~kg}$ lower $(P<0 \cdot 05)$ in sows fed on formic acid. Reproductive performance of sows receiving formic acid as illustrated in terms of litter size and piglet birth weight and weight at weaning was slightly better in the presence of formic acid in pregnancy and lactation diets, but the differences were not statistically significant. Data on health status and agalactia-related indices showed preventive, anti-agalactia properties of formic acid. Folic acid (or folate) plays a major coenzymic role in 1-C metabolism (Kokue et al. 1994). Makar et al. (1990) have shown that the pig compared with all other species has extremely low levels of folates and very low levels of a key enzyme in the folate pathway, 10-formyltetrahydrofolate dehydrogenase. Also, the pig's ability to 
(a)

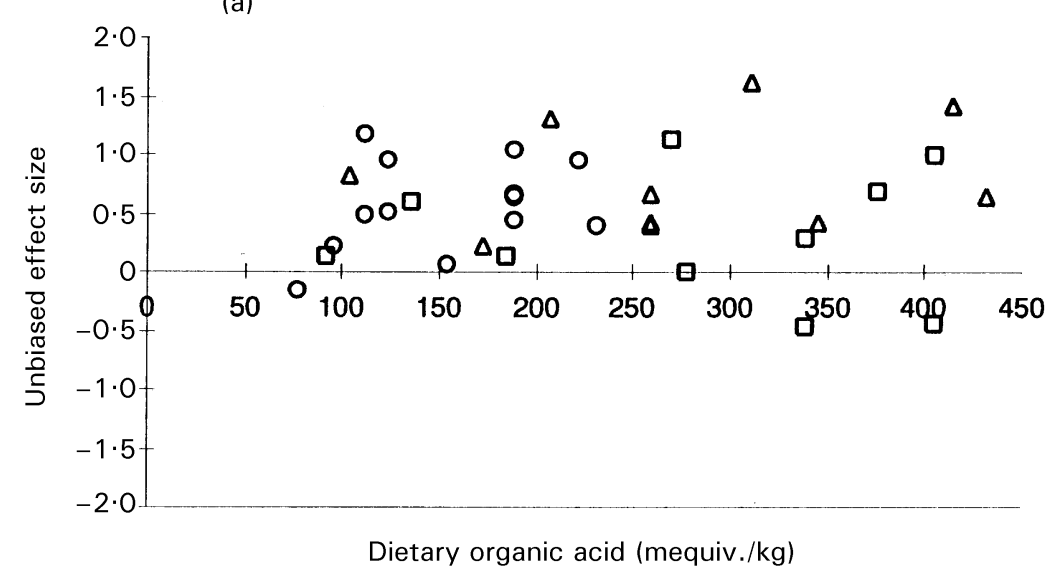

(b)

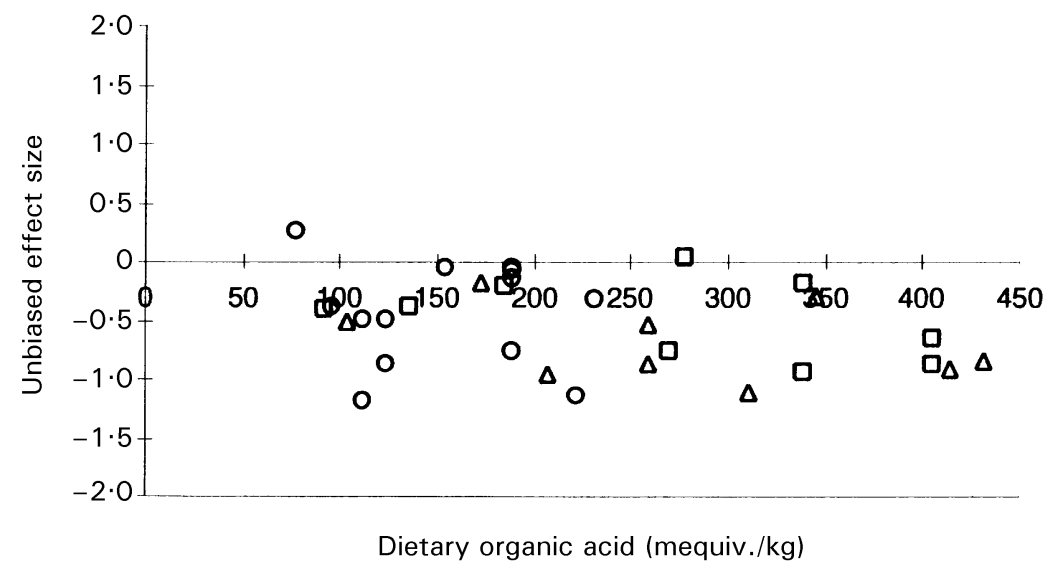

Fig. 3. The effect of dietary formic acid or formates (○), propionic acid or proprionates $(\square)$ and fumaric acid $(\triangle)$ on (a) average daily body weight gain and (b) feed: gain ratio of fattening pigs relative to non-acidified control diet.

dispose of formate was extremely limited and slower than that observed in rats or monkeys. This implies that the rate of formate oxidation is dependent on adequate levels of hepatic folic acid, particularly hepatic tetrahydrofolate. Some studies suggest that the dietary source of folic acid may not be optimal for weanling pigs (Letendre et al. 1991) and sows (Lindemann, 1993). So far, no dose-response interactive effects of formic acid and folic acid levels as two independent variables in diets for pigs have been published. Further studies of formic acid in combination with bioactive folic acid would be desirable.

\section{Physiological factors affected by the action of organic acids}

Successful application of organic acids in diets for pigs requires an understanding of their modes of action. Although several hypotheses have been proposed, their exact mode of action 
still remains unclear. It is generally considered that dietary organic acids or their salts lower gastric $\mathrm{pH}$ and this results in increased activity of proteolytic enzymes and gastric retention time. Due to the lower rate of gastric emptying, large protein molecules may be better hydrolysed, which will have a beneficial effect on protein digestion (Easter, 1988; Kirchgessner \& Roth, 1988; Ravindran \& Kornegay, 1993; Gabert \& Sauer, 1994). A reduced buffering capacity of diets containing organic acids is also expected to slow down the proliferation and/or colonization of undesirable microbes, e.g. E. coli, in the gastro-ileal region. As particular organic acids have strong antimicrobial activities, it seems appropriate that their positive influence on digestion may be related to indirect effects on gastrointestinal microbes. Besides, organic acids can influence mucosal morphology, as well as stimulate pancreatic secretions and serve as substrates in the intermediary metabolism. This multifunctional role of organic acids may lead to the improved digestion, absorption and retention of numerous dietary nutrients.

\section{pH of digesta}

Low gastric $\mathrm{pH}$ is essential for efficient digestion of proteins. Pepsinogens are rapidly activated at $\mathrm{pH}$ 2, but very slowly at $\mathrm{pH} 4$. Pepsin has two $\mathrm{pH}$ optima: 2 and 3.5. Its activity declines rapidly when $\mathrm{pH}$ rises above $3 \cdot 6$, and remains inactive at $\mathrm{pH} 6$ (Kidder \& Manners, 1978). The endproducts of pepsin digestion and the low $\mathrm{pH}$ of digesta entering the duodenum are involved in the stimulation of the pancreatic secretion of enzymes and bicarbonate, and they also play a minor role in regulation of gastric emptying (Maner et al. 1962; Argenzio, 1984). Acid conditions are also needed to prevent passage of potentially harmful microbes to the small intestine. A rise in gastric $\mathrm{pH}$ with inefficient digestion may provide an optimal environment for the colonization of enterotoxigenic haemolytic bacteria on the surface of villi, resulting in the initiation of scours and/or oedema disease in young pigs, particularly after weaning (Smith \& Jones, 1963).

The hypothesis that lowering dietary $\mathrm{pH}$ with organic acids reduces gastrointestinal $\mathrm{pH}$ has been tested in several studies (Table 4). Perhaps owing to methodological imperfections, only a few studies could document that dietary acidification significantly decreased gastric $\mathrm{pH}$ (Bolduan et al. 1988a,b; Eidelsburger et al. 1992b; Radcliffe et al. 1998) whereas most studies have failed to show any significant effect despite quite a large numerical decrease in $\mathrm{pH}$ (Scipioni et al. 1978; Burnell et al. 1988; Risley et al. 1992; Gabert \& Sauer, 1995). High variations in gastric $\mathrm{pH}$ measurements indicate that it is difficult to obtain a representative sample, as the proportions of feed and endogenous excretions can vary from sample to sample. Digesta samples for $\mathrm{pH}$ measurements are generally taken from pigs slaughtered after a certain time postfeeding. As the diurnal variation in gastrointestinal $\mathrm{pH}$ is large, the sampling time should be standardized relative to feeding time, and eventually from specific sections of the stomach. Without cannulation techniques and permanently fixed $\mathrm{pH}$ electrodes for simultaneous measurements in different sections of the stomach and intestine it may be difficult to assess objectively the full effects of dietary organic acids on the gastrointestinal $\mathrm{pH}$.

\section{Rate of gastric emptying}

Mainly the volume of digesta in the stomach and, perhaps to a lesser degree, the $\mathrm{pH}$ in the pyloric region stimulate its emptying rate (Kidder \& Manners, 1978; Mayer, 1994). As already mentioned, at increased acidity of digesta the rate of gastric emptying is reduced, which allows more time for protein hydrolysis in the stomach (Mayer, 1994). Table 4 summarizes the influence of diet acidification on DM content in the stomach, as evaluated post mortem. At a 
Table 4. Influence of dietary organic acids or their salts on $\mathrm{pH}$ values of digesta in different sections of gastrointestinal tract and gastric dry matter content

\begin{tabular}{|c|c|c|c|c|c|c|c|}
\hline \multirow[b]{2}{*}{ Acidifier } & \multirow[b]{2}{*}{ Reference } & \multirow{2}{*}{$\begin{array}{l}\text { Level } \\
\text { (g/kg) }\end{array}$} & \multicolumn{4}{|c|}{ Gastrointestinal $\mathrm{pH}$} & \multirow{2}{*}{$\begin{array}{c}\text { Gastric } \\
\text { dry matter } \\
\text { content }\end{array}$} \\
\hline & & & Gastric & Ileal & Caecal & Colonic & \\
\hline \multirow[t]{7}{*}{ Citric acid } & Scipioni et al. 1978 & 10 & ns & ns & & & \\
\hline & Risley et al. 1991 & 15 & ns & ns & ns & ns & \\
\hline & Risley et al. 1992 & 15 & ns & ns & ns & ns & \\
\hline & Risley et al. 1993 & 15 & ns & ns & ns & ns & \\
\hline & Fasshauer \& Kienzle, 1995 & 10 & & - & & & \\
\hline & Radcliffe et al. 1998 & 15 & - & & & & \\
\hline & & 30 & - & & & & \\
\hline \multirow[t]{8}{*}{ Formic acid } & Bolduan et al. 1988a & 3.5 & - & ns & & & ns \\
\hline & & 12 & - & ns & & & ns \\
\hline & Eidelsburger et al. 1992a & $12 \cdot 5$ & - & ns & ns & ns & ns \\
\hline & Roth et al. $1992 a$ & 6 & ns & ns & ns & ns & ns \\
\hline & & 12 & ns & ns & ns & ns & ns \\
\hline & & 18 & ns & + & + & + & ns \\
\hline & & 24 & ns & + & ns & + & ns \\
\hline & Gabert \& Sauer, 1995 & 10 & & ns & & & \\
\hline \multirow[t]{8}{*}{ Fumaric acid } & Bolduan et al. 1988b & 5 & ns & & & & ns \\
\hline & & 15 & - & & & & ns \\
\hline & Risley et al. 1991 & 15 & ns & ns & ns & ns & \\
\hline & Risley et al. 1992 & 15 & ns & ns & ns & ns & \\
\hline & Risley et al. 1992 & 18 & - & ns & ns & ns & ns \\
\hline & Risley et al. 1993 & 15 & ns & ns & ns & ns & \\
\hline & Gabert \& Sauer, 1995 & 15 & & ns & & & \\
\hline & & 30 & & ns & & & \\
\hline \multirow[t]{2}{*}{ Propionic acid } & Bolduan et al. 1988a & 3 & ns & ns & & & ns \\
\hline & & 10 & ns & ns & & & ns \\
\hline \multirow[t]{2}{*}{ Calcium formate } & Eidelsburger et al. 1992a & 10 & ns & ns & ns & ns & ns \\
\hline & & 18 & ns & ns & ns & ns & ns \\
\hline Sodium formate & Roth et al. $1992 b$ & 18 & ns & ns & ns & ns & - \\
\hline Sodium fumarate & Gabert \& Sauer, 1995 & 15 & & ns & & & ns \\
\hline
\end{tabular}

+ , significant increase in $\mathrm{pH}$ or dry matter content $(P<0.05) ;-$, significant decrease in $\mathrm{pH}$ or dry matter content $(P<0.05)$; ns, no significant influence on $\mathrm{pH}$ or dry matter content.

similar volume ( = meal size) of digesta, DM contents in the stomach reflect proportionally the rate of gastric emptying. Since no statistically significant differences were found in gastric DM contents among the cited studies (except for sodium formate by Roth et al. 1992b), these results do not support the hypothesis that organic acids influence the rate of gastric emptying. Subsequently, if there is no retarded gastric emptying due to organic acids, a meaningful improvement of digestion and absorption of nutrients in the small intestine is less probable. However, bearing in mind the shortcomings of the post mortem technique, more specific, fundamental studies on gastric emptying rate using gastrically and/or duodenally cannulated pigs and markers would be desirable.

\section{Digestibility and retention of nutrients}

Total tract digestibility and retention of nutrients and energy. Several researchers have reported improvements in the apparent total tract digestibility (ATTD) and retention of nutrients with dietary acidification of diets for weaned piglets or fattening pigs (Tables 5 
Table 5. Influence of dietary organic acids or their salts on the apparent total tract digestibility of crude protein and energy and nitrogen balance in weaned piglets

\begin{tabular}{|c|c|c|c|c|c|c|c|c|}
\hline \multirow[b]{2}{*}{ Acid } & \multirow[b]{2}{*}{$(\mathrm{g} / \mathrm{kg})$} & \multirow{2}{*}{$\begin{array}{c}\text { Level } \\
\text { Diet }\end{array}$} & \multicolumn{2}{|c|}{ Crude protein } & \multicolumn{2}{|c|}{ Energy } & \multicolumn{2}{|c|}{ Nitrogen balance } \\
\hline & & & $\mathrm{D}(\%)$ & $\Delta \mathrm{D}$ & $\mathrm{D}(\%)$ & $\mathrm{D}$ & $\mathrm{R}(\%)$ & $\Delta \mathrm{R}$ \\
\hline \multicolumn{9}{|l|}{ Citric acid } \\
\hline Scipioni et al. 1978 & 10 & starter & 84.9 & +2.9 & \multirow{2}{*}{$86 \cdot 5$} & \multirow{2}{*}{$+1 \cdot 2$} & & \\
\hline Falkowski \& Aherne, 1984 & $\begin{array}{l}10 \\
20\end{array}$ & $\begin{array}{l}\text { starter } \\
\text { starter }\end{array}$ & 78.4 & $\begin{array}{l}+0.2 \\
+1.0\end{array}$ & & & & \\
\hline \multirow[t]{3}{*}{ Broz \& Schulze, 1987} & 5 & starter & $80 \cdot 7$ & +0.8 & \multirow[t]{3}{*}{$81 \cdot 0$} & $+1 \cdot 0^{\star}$ & & \\
\hline & 10 & starter & & +1.4 & & $+1.9^{*}$ & & \\
\hline & 15 & starter & & -0.8 & & +0.6 & & \\
\hline \multicolumn{9}{|l|}{ Formic acid } \\
\hline \multirow[t]{8}{*}{ Eckel et al. 1992a } & 6 & prestarter & \multirow[t]{4}{*}{$86 \cdot 2$} & $+2 \cdot 2^{*}$ & \multirow[t]{4}{*}{88.4} & +0.9 & & \\
\hline & 12 & prestarter & & $+2 \cdot 9^{\star}$ & & +1.4 & & \\
\hline & 18 & prestarter & & $+3 \cdot 8^{*}$ & & $+1.9^{*}$ & & \\
\hline & 24 & prestarter & & $+3 \cdot 8^{*}$ & & $+2 \cdot 2^{\star}$ & & \\
\hline & 6 & starter & \multirow[t]{4}{*}{$87 \cdot 0$} & +1.1 & \multirow[t]{4}{*}{$89 \cdot 3$} & +0.7 & & \\
\hline & 12 & starter & & +1.4 & & -0.6 & & \\
\hline & 18 & starter & & $+1 \cdot 2$ & & +0.4 & & \\
\hline & 24 & starter & & $+2 \cdot 6^{\star}$ & & +0.5 & & \\
\hline \multirow[t]{2}{*}{ Eidelsburger et al. 1992d } & 12.5 & prestarter & \multirow{4}{*}{$\begin{array}{l}87.8 \\
86.3 \\
89.2\end{array}$} & $+2 \cdot 0^{*}$ & \multirow{4}{*}{$\begin{array}{l}89.2 \\
87.7 \\
86.6\end{array}$} & +0.5 & & \\
\hline & 12.5 & starter & & +1.0 & & +0.7 & & \\
\hline Gabert \& Sauer, 1995 & 15 & starter & & -0.2 & & -0.2 & & \\
\hline & 30 & starter & & -0.8 & & -0.9 & & \\
\hline \multicolumn{9}{|l|}{ Sodium formate } \\
\hline Gabert \& Sauer, 1995 & 15 & starter & $89 \cdot 2$ & -1.4 & $86 \cdot 6$ & -0.7 & & \\
\hline \multicolumn{9}{|l|}{ Calcium formate } \\
\hline Eidelsburger et al. 1992d & 18 & prestarter & 87.8 & $+1 \cdot 7^{\star}$ & 89.2 & +0.7 & & \\
\hline & 18 & starter & $86 \cdot 3$ & $+1 \cdot 3$ & 87.7 & $+1 \cdot 0$ & & \\
\hline Fumaric acid & & & & & & & & \\
\hline Scipioni et al. 1978 & 7 & starter & 84.9 & -2.4 & 86.5 & -2.2 & & \\
\hline Kirchgessner \& Roth, $1978 b$ & 18 & prestarter & 84.0 & +0.8 & $80 \cdot 2$ & $+1 \cdot 6^{\star}$ & & \\
\hline & 18 & starter & 84.9 & +1.0 & $82 \cdot \overline{6}$ & +0.5 & & \\
\hline Kirchgessner \& Roth, 1980 & 10 & starter & $85 \cdot 2$ & $+2 \cdot 1$ & $85 \cdot 9$ & $+1 \cdot 3^{*}$ & 61.5 & $+3 \cdot 1^{*}$ \\
\hline & 20 & starter & & $+2 \cdot 5^{\star}$ & & $+1 \cdot 8^{\star}$ & & $+4 \cdot 1^{*}$ \\
\hline Falkowski \& Aherne, 1984 & 10 & starter & 78.4 & +0.5 & & & & \\
\hline & 20 & starter & & +1.4 & & & & \\
\hline Eidelsburger et al. $1992 b$ & 18 & prestarter & $87 \cdot 1$ & +0.4 & 88.4 & +0.6 & & \\
\hline & 18 & starter & 86.4 & +1.0 & $87 \cdot 7$ & -0.2 & & \\
\hline Propionic acid & & & & & & & & \\
\hline Kirchgessner \& Roth, 1982 & 10 & prestarter & 84.5 & +1.5 & 81.9 & +1.4 & $60 \cdot 1$ & $+1 \cdot 0$ \\
\hline & 20 & prestarter & & $+1 \cdot 6$ & & $+2 \cdot 2^{*}$ & & $+1 \cdot 8$ \\
\hline & 10 & starter & 83.0 & +0.2 & 81.5 & -0.1 & $50 \cdot 7$ & +0.3 \\
\hline & 20 & starter & & $+0 . \overline{5}$ & & +0.7 & & +1.5 \\
\hline Calcium propionate & & & & & & & & \\
\hline Roth \& Kirchgessner, 1982 & 10 & prestarter & $84 \cdot 5$ & +1.5 & 81.9 & +1.4 & & \\
\hline & 20 & prestarter & & +1.6 & & $+2 \cdot 2^{*}$ & & \\
\hline & 10 & starter & $83 \cdot 0$ & $+0 \cdot 2$ & 81.5 & -0.1 & & \\
\hline & 20 & starter & & +0.5 & & +0.7 & & \\
\hline
\end{tabular}

$\mathrm{D}$, digestibility of non-acidified control diet; $\Delta \mathrm{D}$, \%-unit change in the digestibility relative to the non-acidified control diet; $R$, nitrogen retention of non-acidified control diet as percentage of intake; $\Delta \mathrm{R}, \%$-unit change in the nitrogen retention relative to the non-acidified control diet.

* Significantly different from the control diet $(P<0.05)$. 
and 6). In particular, organic acids exerted a small, positive influence on the ATTD and retention of crude protein (CP) and energy, whereas the influences on other nutrients were found to be less consistent.

The effect of organic acids on ATTD of nutrients and energy seems to depend on the type and level of acid applied. In several experiments, citric-acid exerted no significant influence on ATTD of CP or N retention (Falkowski \& Aherne, 1984; Broz \& Schulze, 1987; Pallauf et al. 1988), although improved digestibilities of organic matter and gross energy have been observed (Broz \& Schulze, 1987; Pallauf et al. 1988). Citric acid is metabolized through the citric-acid cycle, and may act as an energy source. A positive effect of fumaric acid on ATTD of organic matter, crude fat (diethyl ether extract) and $\mathrm{CP}$, and on $\mathrm{N}$ retention have been reported by Kirchgessner \& Roth $(1978 b ; 1980)$. However, several researchers have failed to observe any effect of these organic acids on the digestibility of $\mathrm{CP}$ and energy or $\mathrm{N}$ retention (Falkowski \& Aherne, 1984; Radecki et al. 1988; Giesting \& Easter, 1991; Eidelsburger et al. 1992b).

Formic acid appears primarily to affect ATTD of CP, whereas the influence on ATTD of organic matter and energy seems to be smaller. Eckel et al. (1992a) reported that ATTD of CP increased by $2.6 \%$ to $4.4 \%(P<0.05)$ when complex starter diets designed for piglets from 6 to $14 \mathrm{~kg} \mathrm{BW}$ were supplemented with 6-24 g formic acid $/ \mathrm{kg}$ diet. However, the authors found no effect in the subsequent period between 14 and $23 \mathrm{~kg} \mathrm{BW}$. The improvement in digestibility of gross energy was significant only at the highest inclusion levels of formic acid $(18-24 \mathrm{~g} / \mathrm{kg}$ diet) in the starter diet. Similarly, Eidelsburger et al. $(1992 a, d)$ found that formic acid $(12.5 \mathrm{~g} / \mathrm{kg}$ diet $)$, calcium formate $(18 \mathrm{~g} / \mathrm{kg})$ and sodium formate $(18 \mathrm{~g} / \mathrm{kg})$ improved ATTD of $\mathrm{CP}$ when added to a complex starter diet for piglets between 6 and $14 \mathrm{~kg} \mathrm{BW}$, but not in the subsequent period. It seems that the influence of formic acid or its salts on the digestibility of

Table 6. Influence of dietary organic acids or their salts on the apparent total tract digestibility of crude protein and energy and nitrogen balance in growing pigs

\begin{tabular}{|c|c|c|c|c|c|c|c|c|}
\hline \multirow[b]{2}{*}{ Acid } & \multirow{2}{*}{$\begin{array}{l}\text { Level } \\
(\mathrm{g} / \mathrm{kg})\end{array}$} & \multirow[b]{2}{*}{ Diet } & \multicolumn{2}{|c|}{ Crude protein } & \multicolumn{2}{|c|}{ Energy } & \multicolumn{2}{|c|}{ Nitrogen balance } \\
\hline & & & $\mathrm{D}(\%)$ & $\Delta \mathrm{D}$ & $\mathrm{D}(\%)$ & $\Delta \mathrm{D}$ & $\mathrm{R}(\%)$ & $\Delta \mathrm{R}$ \\
\hline Butyric acid & & & & & & & & \\
\hline $\begin{array}{l}\text { Mroz et al. } 1997 \\
\text { Formic acid }\end{array}$ & $26 \cdot 7$ & grower & $80 \cdot 6$ & $+1 \cdot 4$ & $82 \cdot 2$ & $+1 \cdot 8$ & $48 \cdot 3$ & $+4 \cdot 0^{* \star}$ \\
\hline $\begin{array}{l}\text { Mroz et al. } 1997 \\
\text { Fumaric acid }\end{array}$ & $13 \cdot 8$ & grower & 80.6 & $+1 \cdot 4$ & $82 \cdot 2$ & +0.7 & $48 \cdot 3$ & $+4 \cdot 9^{*}$ \\
\hline $\begin{array}{l}\text { Mroz et al. } 1997 \\
\text { Propionic acid }\end{array}$ & $17 \cdot 6$ & grower & 80.6 & $-1 \cdot 0$ & $82 \cdot 2$ & +1.4 & $48 \cdot 3$ & $+2 \cdot 9^{*}$ \\
\hline Kirchgessner \& Roth, 1992 & $\begin{array}{l}10 \\
20 \\
10 \\
20\end{array}$ & $\begin{array}{l}\text { grower } \\
\text { grower } \\
\text { finisher } \\
\text { finisher }\end{array}$ & $\begin{array}{l}79.7 \\
78.5\end{array}$ & $\begin{array}{l}+0.3 \\
+1.7 \\
+1.3 \\
+0.1\end{array}$ & $\begin{array}{l}77 \cdot 3 \\
77 \cdot 1\end{array}$ & $\begin{array}{l}+0.3 \\
+0.8 \\
-0.6 \\
-1.7\end{array}$ & $\begin{array}{l}43.2 \\
38.0\end{array}$ & $\begin{array}{l}-1.1 \\
+3.8 \\
-0.4 \\
+0.2\end{array}$ \\
\hline $\begin{array}{l}\text { Mosenthin et al. } 1992 \\
\text { Calcium propionate }\end{array}$ & 20 & grower & $80 \cdot 2$ & $+2 \cdot 3$ & $77 \cdot 9$ & $+1 \cdot 4$ & & \\
\hline Roth \& Kirchgessner, 1982 & $\begin{array}{l}10 \\
20 \\
10 \\
20\end{array}$ & $\begin{array}{l}\text { grower } \\
\text { grower } \\
\text { finisher } \\
\text { finisher }\end{array}$ & $\begin{array}{l}79.7 \\
78.5\end{array}$ & $\begin{array}{l}+0.3 \\
+1.7 \\
+1.3 \\
+0.1\end{array}$ & $\begin{array}{l}77 \cdot 3 \\
77 \cdot 1\end{array}$ & $\begin{array}{l}+0.3 \\
+0.8 \\
-0.6 \\
-1.7\end{array}$ & & \\
\hline
\end{tabular}

$\mathrm{D}$, digestibility of non-acidified control diet; $\Delta \mathrm{D}, \%$-unit change in the digestibility relative to the non-acidified control diet; $R$, nitrogen retention of non-acidified control diet as percentage of intake; $\Delta R$, \%-unit change in the nitrogen retention relative to the non-acidified control diet.

* Significantly different from the control diet $(P<0.05)$. 
$\mathrm{CP}$ is most effective in young piglets with immature digestive systems, and the effect diminishes when the pig matures. However, it should be noted that formic acid has been shown to improve ATTD of nutrients in growing pigs (Jongbloed \& Jongbloed, 1996). Using the comparative slaughter technique, Kirchgessner et al. (1992) studied the effect of formic acid supplementation $(6-24 \mathrm{~g} / \mathrm{kg} \mathrm{diet})$ on protein, fat, ash and energy retention in weaned piglets. They found that all formic acid-supplemented diets resulted in increased carcass protein content. Compared with the control group, the retention of protein was higher $(P<0 \cdot 05)$ in pigs fed on diets with $6-18 \mathrm{~g}$ formic acid $/ \mathrm{kg}$ diet, and averaged $61 \mathrm{~g} / \mathrm{d}$. Also, at low levels of supplementary formic acid $(6-12 \mathrm{~g} / \mathrm{kg}$ diet), energy retention was enhanced.

Kirchgessner \& Roth (1982) reported that supplementation with propionic acid had no effect on ATTD of DM, CP or gross energy. Similar results have been reported by Bolduan et al. (1988a). Recently, Jongbloed \& Jongbloed (1996) found that propionic acid supplementation increased ATTD of DM and ash, but not that of organic matter. Similar observations were made with lactic acid, which is in agreement with earlier results of Jongbloed et al. (1995).

Ileal digestibility of protein and amino acids. Data on the effects of organic acids on the apparent ileal digestibility (AID) of CP and amino acids is scarce. Giesting \& Easter (1991) were first to report a non-significant increase in the AID of crude protein when fumaric acid $20 \mathrm{~g}$ furmaric acid/ $\mathrm{kg}$ diet was added to a maize-soyabean meal diet. However, no response

Table 7. Influence of dietary organic acids or their salts on the apparent ileal digestibility of crude protein and amino acids in piglets

\begin{tabular}{|c|c|c|c|c|c|c|c|c|}
\hline \multirow{3}{*}{$\begin{array}{l}\text { Reference.... } \\
\text { Diet/acidifier... }\end{array}$} & \multicolumn{4}{|c|}{ Gabert et al. 1995} & \multicolumn{4}{|c|}{ Gabert \& Sauer, 1995} \\
\hline & \multicolumn{2}{|c|}{ SFM(n) For(10) } & \multicolumn{2}{|c|}{ SFM(h) For(10) } & \multicolumn{2}{|c|}{ WSM Fum(10) } & \multirow{2}{*}{$\frac{\text { Fum(30) }}{\Delta \mathrm{D}}$} & \multirow{2}{*}{$\frac{\text { Na-fum(15) }}{\Delta \mathrm{D}}$} \\
\hline & $\mathrm{D}(\%)$ & $\Delta \mathrm{D}$ & $\mathrm{D}(\%)$ & $\Delta \mathrm{D}$ & $\mathrm{D}(\%)$ & $\Delta \mathrm{D}$ & & \\
\hline Crude protein & 79.5 & -1.7 & $79 \cdot 3$ & $-4 \cdot 1$ & $80 \cdot 3$ & -0.4 & $-4 \cdot 1^{*}$ & $-1 \cdot 1$ \\
\hline Arginine & 88.8 & +1.0 & 89.4 & -2.1 & 87.2 & -1.4 & $-4.5^{\star}$ & -1.6 \\
\hline Histidine & 85.5 & -0.9 & 85.5 & -1.8 & 85.6 & +0.5 & $-1 \cdot 3$ & -0.9 \\
\hline Isoleucine & $85 \cdot 3$ & +0.7 & 86.6 & -3.6 & 85.1 & -0.5 & -1.4 & -1.5 \\
\hline Leucine & 85.7 & 0.0 & 86.0 & $-3 \cdot 1$ & $85 \cdot 3$ & -0.9 & $-2 \cdot 1$ & -1.7 \\
\hline Lysine & 89.0 & +0.4 & 90.9 & $-3 \cdot 2$ & 82.6 & -1.0 & -1.8 & -1.9 \\
\hline Methionine & - & - & - & - & - & - & - & - \\
\hline Phenylalanine & 82.4 & +0.4 & 83.1 & -3.4 & 85.0 & $-1 \cdot 2$ & -3.0 & -3.0 \\
\hline Threonine & 79.7 & -0.6 & $80 \cdot 3$ & $-5 \cdot 6$ & 75.5 & 0.0 & -1.5 & $-1 \cdot 8$ \\
\hline Tryptophan & - & - & - & - & - & - & - & - \\
\hline Valine & 84.3 & +0.4 & 85.7 & -3.8 & 82.4 & -0.2 & -1.6 & $-2 \cdot 1$ \\
\hline \multicolumn{9}{|c|}{ Nonessential amino acid } \\
\hline Alanine & 85.1 & +1.0 & 86.0 & $-2 \cdot 3$ & $76 \cdot 2$ & +0.2 & $-2 \cdot 7$ & -1.8 \\
\hline Aspartate & 79.8 & $-2 \cdot 2$ & 80.1 & -4.3 & 79.8 & $+0 . \overline{6}$ & -0.8 & -0.1 \\
\hline Cystine & - & - & - & - & - & - & - & - \\
\hline Glutamate & 85.6 & +0.6 & 87.6 & -4.7 & $90 \cdot 8$ & 0.0 & $-1 \cdot 7$ & -0.5 \\
\hline Glycine & 78.0 & -1.0 & 76.6 & -2.7 & $67 \cdot 7$ & $-1 \cdot 2$ & $-9 \cdot 7^{\star}$ & $-1 \cdot 2$ \\
\hline Proline & - & - & - & - & - & - & - & - \\
\hline Serine & 79.7 & -1.5 & 79.1 & -4.0 & 80.4 & +0.1 & -1.8 & $-1 \cdot 2$ \\
\hline Tyrosine & 84.4 & +0.1 & 84.5 & $-2 \cdot 8$ & 83.0 & +0.7 & $-3 \cdot 5^{\star}$ & -1.1 \\
\hline
\end{tabular}

Diet: SFM, semipurified fishmeal diet with normal $(\mathrm{n})$ or high (h) buffering capacity; WSM, wheat-soyabean meal diet. Acidifier $(\mathrm{g} / \mathrm{kg})$ : For, formic acid; Fum, fumaric acid; Na-fum, sodium fumarate. D, digestibility of non-acidified control diet; $\Delta \mathrm{D}$, \%-unit change in the digestibility relative to the non-acidified control diet.

* Significantly different from the control diet $(P<0.05)$. 


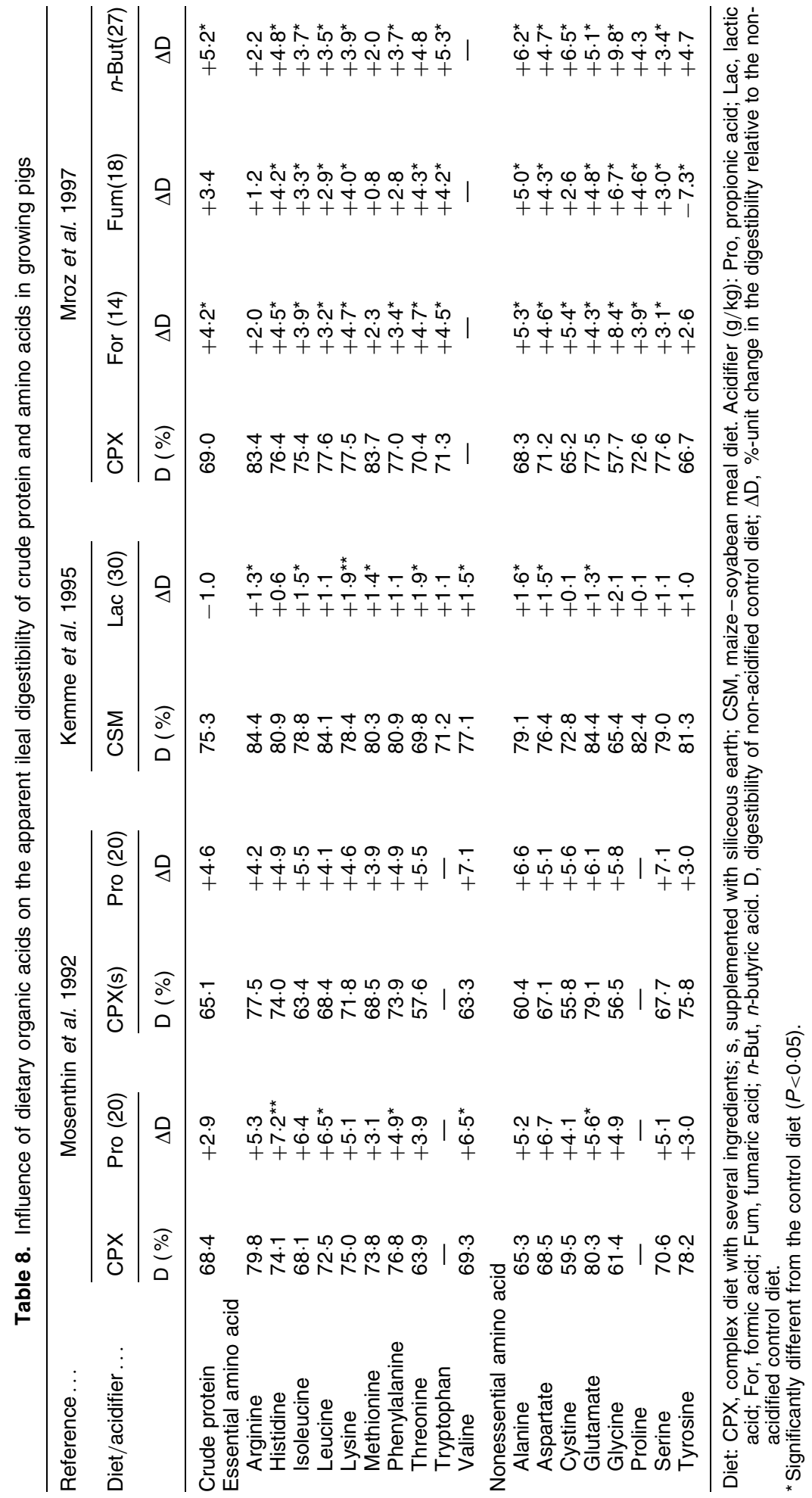


was noted with diets containing dried skim milk. On the other hand, Bolduan et al. (1988b) reported no effect of formic acid on the AID of crude protein. So far, only a few studies have been reported in the literature in which the effects of supplementation of organic acids or their salts on the AID of amino acids have been determined. The results of these studies are summarized in Tables 7 and 8.

According to Mosenthin et al. (1992), propionic acid supplementation of grower diets improved $(P<0.05)$ the AID of several indispensable amino acids: arginine, histidine, leucine, phenylalanine and valine. Kemme et al. (1995) observed with growing pigs that dietary lactic acid supplementation improved $(P<0.05)$ the AID of arginine, isoleucine, lysine, methionine, phenylalanine, threonine and valine. Recently, Mroz et al. (1997) reported that formic, fumaric and $n$-butyric acids improved the AID of several essential and nonessential amino acids by 3-6\% units $(P<0 \cdot 05)$. However, opposite results have been obtained with weaned piglets. Neither formic acid (Gabert et al. 1995), fumaric acid nor sodium fumarate (Gabert \& Sauer, 1995) supplementation has been found to affect the AID of amino acids $(P>0.05)$. The diets used in studies with weaned piglets were either simple cereal-soyabean meal (Gabert \& Sauer, 1995) or semipurified fishmeal diets (Gabert et al. 1995) whereas those used in studies with growing pigs were either simple maize-soyabean meal (Kemme et al. 1995) or complex byproduct-based diets (Mosenthin et al. 1992; Mroz et al. 1997). Based on the available data, it is unclear whether differences in the effect on protein and amino acid digestibility are due to acidifier and its inclusion level, diet composition or the age of the pigs. It seems that when feedstuffs of high digestibility are used, a small improvement in the digestibility can be expected. So far, no information is available on the influences of dietary organic acids on endogenous protein excretion and true digestibility of amino acids.

Absorption and retention of minerals. Organic acids may improve the absorption of minerals, particularly Ca and P (Kirchgessner \& Roth, 1980; Höhler \& Pallauf, 1993; Jongbloed et al. 1995; Jongbloed \& Jongbloed, 1996), although opposite results have also been reported (Radecki et al. 1988). All organic acids studied (citric, formic, fumaric, lactic, and propionic) seem to have a positive effect on $\mathrm{Ca}$ and $\mathrm{P}$ absorption. Jongbloed (1987) suggested that lowered intestinal $\mathrm{pH}$ increases the solubility of $\mathrm{P}$, which may improve its absorption. However, the data on ileal $\mathrm{pH}$ (Table 3) do not support this assumption. The effects of organic acids on $\mathrm{P}$ digestibility are also dependent on the amount of phytase (EC 3.1.3.26), either intrinsic or of microbial origin, in the diet. Results of Jongbloed et al. (1995) and Jongbloed \& Jongbloed (1996) indicate that organic acids may have an additional improving effect on the efficacy of phytase. A synergic effect of lactic acid and microbial phytase was reported in the study of Jongbloed et al. (1995). However, in the study of Radcliffe et al. (1998) no synergic effects were observed with citric-acid, and Jongbloed \& Jongbloed (1996) showed it only for formic acid. Dietary organic acid supplementation improving P absorption and the efficacy of microbial phytase may thus contribute to reduced $\mathrm{P}$ excretion in the faeces.

Organic acids also appear to influence the retention of minerals. Kirchgessner \& Roth (1980) reported that $20 \mathrm{~g}$ fumaric acid $/ \mathrm{kg}$ diet in a weaner diet improved the balance of $\mathrm{Ca}, \mathrm{P}$, $\mathrm{Mg}$ and $\mathrm{Zn}$ by 14, 13, 21 and $43 \%$ respectively. The magnitude of effect of organic acids depends on the type of diet and dietary mineral content. In diets with suboptimal levels of $\mathrm{Zn}$, $15 \mathrm{~g}$ citric-acid/kg diet supplementation has reduced $\mathrm{Zn}$ deficiency symptoms (parakeratosis), but no significant effects on the apparent absorption and retention of $\mathrm{Zn}$ or other minerals $(\mathrm{Ca}$, $\mathrm{P}, \mathrm{Mg}, \mathrm{Fe}, \mathrm{Cu}$, and $\mathrm{Mn}$ ) has been found (Höhler \& Pallauf, 1993, 1994).

Diet-induced changes in the blood acid-base status are important in affecting mineral retention. The retention of $\mathrm{Ca}$ and $\mathrm{P}$ can be lowered when animals are fed on strongly acidic 
diets, not owing to a reduction in intestinal $\mathrm{Ca}$ and $\mathrm{P}$ absorption but rather to a cell-mediated increase in bone resorption and associated changes in urinary mineral excretion (Abu Damir et al. 1991). Acidic diets can cause bone erosion due to the use of bone as a buffer for the body acid-base system (Petito \& Evans, 1984). Chronic ingestion of $\mathrm{NH}_{4} \mathrm{Cl}$ results in a significant loss of bone tissue, including both the organic and inorganic phases of the bone, due to increased resorption (Barzel \& Jowsey, 1969). Also, Mroz et al. (1996) reported a significant reduction in retention of $\mathrm{P}$ when $\mathrm{CaCO}_{3}$ was partly replaced with $\mathrm{CaCl}_{2}$ or calcium benzoate in diets for growing gilts.

Straw et al. (1991) manipulated dietary $\mathrm{pH}$ from 5.4 to 6.7 with different mineral $\mathrm{Na}$ sources but observed no effect on bone development of weaned piglets. Kornegay et al. (1994) reported that the effect of acidification on bone stress values depended on dietary protein content. Increased stress values were observed with diets containing $160 \mathrm{~g} \mathrm{CP} / \mathrm{kg}$ compared with diets with $220 \mathrm{~g} \mathrm{CP} / \mathrm{kg}$. The authors suggested that dietary protein can act as a buffer to modify the acidic potential. Radcliffe et al. (1998) observed no effect of citric-acid supplementation on bone shear force, but reported a tendency $(P<0.08)$ for a linear increase in bone ash content with increasing level of acid in the diet.

\section{Gastrointestinal microflora}

Stress associated with weaning of piglets is known to disturb the intestinal microflora. It is well known that low luminal $\mathrm{pH}$ and rapid flow of digesta can markedly inhibit growth of microbes along the whole gastrointestinal tract (Maxwell \& Stewart, 1995). It has also been shown that acidic conditions favour the growth of lactobacilli in the stomach (Fuller, 1977), which possibly inhibits the colonization and proliferation of $E$. coli by blocking the sites of adhesion or by producing lactic acid and other metabolites which lower the $\mathrm{pH}$ and inhibit E. coli.

Influence of microbial counts. Several reports have shown that the use of organic acids may reduce the coliform burden along the gastrointestinal tract (Cole et al. 1968; Scipioni et al. 1978; Thomlinson \& Lawrence, 1981; Bolduan et al. 1988b; Mathew et al. 1991) and reduce scouring and piglet mortality. In segments of the small intestine, micro-organism counts of Lactobacillus/Bifidobacterium, Eubacterium and Bacteroidaceae were slightly decreased by the addition of 6-24 $\mathrm{g}$ formic acid/ $\mathrm{kg}$ diet (Gedek et al. 1992a). The effect on E. coli counts in ileal digesta were not consistent, the highest counts being observed for diets supplemented with $18 \mathrm{~g}$ formic acid $/ \mathrm{kg}$ diet. In the caecum and colon the counts of Lactobacillus/Bifidobacterium and $E$. coli were decreased $(P<0.05)$ irrespective of the level of formic acid supplementation. Counts of Lactobacillus/Bifidobacterium, Eubacterium spp. and also the sum of the main flora in the duodenum, jejunum and ileum were significantly reduced by the addition of $18 \mathrm{~g}$ fumaric acid $/ \mathrm{kg}$ diet (Gedek et al. 1992b). The influence of sodium formate was less profound. Fumaric acid also reduced the Lactobacillus/Bifidobacterium counts in the caecum and colon. E. coli counts were reduced in the jejunum by fumaric acid treatment, but not in other segments of the gastrointestinal tract.

In contrast, dietary organic acid supplementation ( $15 \mathrm{~g}$ citric or fumaric acid $/ \mathrm{kg} \mathrm{diet}) \mathrm{did}$ not prevent the $E$. coli challenge from causing scouring and a growth lag in the studies of Risley et al. (1993). Organic acids had no effect on E. coli or Lactobacillus counts in different sections of the gastrointestinal tract. Clark \& Batterham (1989) also failed to observe any effect of acidification on the incidence of scours. Risley et al. (1992) reported that $15 \mathrm{~g}$ citric or fumaric 
acid/kg diet had no appreciable effect on lactobacilli, clostridia or E. coli numbers in the stomach, jejunum, caecum, or colon of piglets. No E. coli were found in the stomach of piglets fed on diets supplemented with $10 \mathrm{~g}$ propionic acid or 3.5-12 $\mathrm{g}$ formic acid $/ \mathrm{kg}$ diet (Bolduan et al. 1988a). Total bacteria contents were not significantly affected by organic acid supplementation.

Influence of fermentation patterns. Supplementation of $20 \mathrm{~g}$ propionic acid $/ \mathrm{kg}$ diet did not affect the concentrations of $\mathrm{NH}_{3}$, cadaverine or putrescine in ileal digesta $(P>0.05)$, but decreased the concentration of cadaverine in caecal digesta (Mosenthin et al. 1992). With increasing formic acid dosage $(6,12,18$ and $24 \mathrm{~g} / \mathrm{kg}$ diet), concentrations of volatile fatty acids (VFA) in the stomach and small intestine remained unchanged. In the caecum and colon butyric acid content was lowered. In the colon the concentrations of acetic and propionic acids and total VFA were diminished by adding 18 and $24 \mathrm{~g}$ formic acid/ $\mathrm{kg}$ diet. In the whole large intestine the proportions of VFA were shifted to higher proportions of acetic acid largely at the expense of propionic and to a lesser extent butyric acids. Lactic acid concentration was decreased with increasing formic acid dosage, but no effect was observed in the stomach, caecum or colon (Roth et al. 1992a).

$\mathrm{NH}_{3}$ content in the stomach was lowered $(P<0.05)$ by increasing dosage of formic acid $(6-24 \mathrm{~g} / \mathrm{kg} \mathrm{diet})$, but was not significantly affected in other parts of the gastrointestinal tract (small intestine, caecum and colon; Eckel et al. 1992b). In the small intestine, concentrations of biogenic amines (cadaverine, putrescine, and spermidine) were not affected by formic acid supplementation, but were generally diminished in the caecum. In the stomach and small intestine, $\mathrm{NH}_{3}$ content was significantly lowered by addition of $12.5 \mathrm{~g}$ formic acid $/ \mathrm{kg}$ diet, whereas the buffer $\left(\mathrm{NaHCO}_{3}\right)$ increased $\mathrm{NH}_{3}$ content (Eidelsburger et al. 1992a). Formic acid also decreased the lactic acid content in the stomach $(P<0.05)$. In the caecum, contents of VFA were slightly lowered by formic acid and calcium formate supplementation, but were always increased with the addition of buffer. In caecum and colon contents, some VFA shifted to higher proportions of acetic acid at the cost of butyric acid. Neither fumaric acid ( 15 or $30 \mathrm{~g} / \mathrm{kg}$ diet) nor sodium fumarate $(15 \mathrm{~g} / \mathrm{kg}$ diet $)$ affected acetate or propionate concentrations in ileal digesta. For diets supplemented with fumaric acid, concentrations of butyrate increased quadratically $(P<0.05)$ with increased acid dose (Gabert \& Sauer, 1995). Formic acid $(10 \mathrm{~g} / \mathrm{kg}$ diet) did not affect VFA concentrations in ileal digesta (Gabert et al. 1995).

\section{Pancreatic enzyme secretion}

A series of hormonal mechanisms via the autonomic nervous system are set in action by the ingestion of food, which activates and controls pancreatic secretion of water, electrolytes and digestive enzymes (Solomon, 1994). Some results indicate that short-chain fatty acids have a stimulatory effect on both endocrine and exocrine pancreatic secretions in pigs (Harada et al. 1986; Sano et al. 1995), as well as in sheep (Harada \& Kato, 1983) and calves (Kato et al. 1989).

Using anaesthetized piglets, Harada et al. (1986) observed that pancreatic secretory responses induced by intraduodenal instillation of $\mathrm{HCl}$ or lactic acid were dependent on $\mathrm{pH}$. For

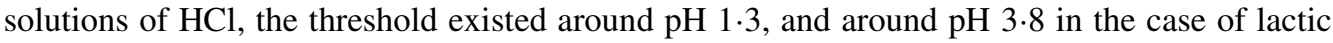
acid. Above these $\mathrm{pH}$ values secretin was not released in amounts sufficient to stimulate pancreatic exocrine secretion. Pancreatic exocrine responses induced by other monocarboxylic acid solutions $(250 \mathrm{mM})$ of $\mathrm{pH} 2.0$ were ranked as: formic acid $>$ lactic acid $>$ pyruvic acid $>$ acetic acid $>$ butyric acid $>$ propionic acid. In anaesthetized sheep, pancreatic juice flow, amylase, and protein outputs rapidly increased after intrajugular injection of acetate, propio- 
nate, and butyrate. Secretory response to butyrate was significantly greater than that observed with propionate or acetate. Rapid intravenous injection of butyrate $(625 \mu \mathrm{mol} / \mathrm{kg} \mathrm{BW})$ caused a 13-fold rise in the juice flow, 26-fold increase in protein output, and 37-fold increase in amylase output above basal levels within $5 \mathrm{~min}$, which declined to basal levels over a period of $30 \mathrm{~min}$ (Harada \& Kato, 1983). Similarly, with 2-week-old calves, which were given only whole milk and milk replacers and therefore considered as nonruminants, intravenous injections of sodium acetate, propionate or butyrate $(625 \mathrm{mmol} / \mathrm{kg} \mathrm{BW})$ stimulated pancreatic juice secretion and protein and amylase output (Kato et al. 1989). Responses increased with increasing fatty acid chain length, butyrate being the most effective stimulant.

Intestinal acidification either with $\mathrm{HCl}$ or monocarboxylic acids elevates serum secretin content in pigs (Harada et al. 1986, 1988). Both pancreatic exocrine secretion and biliary excretion are stimulated via the release of secretin (Harada et al. 1988). In an experiment with growing gilts of $25 \mathrm{~kg} \mathrm{BW}$, an intravenously injected supraphysiological dose $(2.5 \mathrm{mmol} / \mathrm{kg}$ BW) of $n$-butyrate increased plasma glucagon concentrations $(P<0.05)$ following an initial temporary decrease $(P<0 \cdot 05)$. A similar tendency was observed after acetate or propionate injection. However, plasma insulin concentrations were not influenced by injections of VFA. Results suggest that supraphysiological doses of acetate, propionate or $n$-butyrate may stimulate plasma glucagon responses in growing piglets (Sano et al. 1995).

\section{Gut morphology}

At weaning the small intestine of the piglet generally undergoes a reduction in villous height and an increase in crypt depth, changes which are associated with decreased absorption capacity (Cera et al. 1988; Nabuurs, 1995; Pluske et al. 1996). Similar changes are observed in the epithelium of the small intestine with a reduction in voluntary food intake (Pluske et al. 1996) and postweaning diarrhoea (Nabuurs, 1995). Changes in gut morphology are important as they can reduce growth and prolong the time pigs take to reach slaughter weight. According to Pluske et al. (1996), weight gain of weaned piglets is positively correlated with villous height.

Villous shortening and crypt deepening after weaning can be partly prevented by giving piglets supplementary feed during suckling (Nabuurs, 1995) or by feeding weaned piglets with a liquid milk diet (Pluske et al. 1996). So far, little is known about the influence of dietary acidification on pig gut morphology. Gálfi \& Bokori (1990) observed that $1.7 \mathrm{~g} / \mathrm{kg}$ sodium butyrate in the diet resulted in a substantial increase in the number of cells $(33.5 \%)$ constituting microvilli, and in the length of microvilli $(30.1 \%)$ in the ileum of growing pigs. Pigs also grew faster than in the control group. Whether other dietary acidifiers have similar effects is not known. However, it is well known that short-chain fatty acids (acetic, propionic and $n$-butyric acid) produced by microbial fermentation of carbohydrates stimulate epithelial cell proliferation (Lupton \& Kurtz, 1993; Sakata et al. 1995; Marsman \& McBurney, 1996). The strength of the effect is in the order $n$-butyric $>$ propionic $>$ acetic acid (Sakata, 1987). Increased epithelial cell proliferation has also been observed when short-chain fatty acids have been given orally or provided by intravenous or gastrointestinal infusions (Frankel et al. 1994; Sakata et al. 1995), as dietary organic acids can influence fermentation patterns in the small intestine, and may indirectly influence intestinal morphology.

\section{Intermediary metabolism}

Kirchgessner \& Roth (1988) have proposed that organic acids may stimulate intermediary metabolism resulting in improved energy or protein/amino acid utilization. Grassmann et al. 
(1992) found that formic acid addition to weaner diets increased the activities of $\alpha$-ketoglutaric dehydrogenase (EC 1.2.4.2) and glutamate-pyruvate transaminase (EC 2.6.1.15), when diets were supplemented with 18 or $24 \mathrm{~g}$ formic acid $/ \mathrm{kg}$. Imoto \& Namioka (1983) fed acetate in the form of triacetin to growing pigs, at 0,5 and $10 \%$ of metabolizable energy intake. Weight gain and $\mathrm{N}$ retention showed a linear increase $(P<0.001)$ with increasing levels of acetate. The efficiency of acetate utilization for BW gain was $0.90 \mathrm{~g} / \mathrm{g}$ acetate, and the mean $\mathrm{N}$-sparing effect of acetate was $32.9 \mathrm{mg} \mathrm{N} / \mathrm{g}$ acetate. A linear increase was observed in the weights of liver, heart and femoral muscle $(P<0.01)$, and in their protein $(P<0.01)$ and RNA $(P<0.05)$ content with increased acetate intake. However, the total DNA content did not change, indicating that acetate had no effect on the number of nuclei or the number of cells in the tissues. However, in practical conditions supplementation of diets with acetic acid has not resulted in increased average daily gain or improved gain : feed ratio (Zhang et al. 1986; Roth \& Kirchgessner, 1988).

Tschierschwitz et al. (1982) and Grassmann \& Klasna (1986) investigated the effects of dietary fumaric acid supplementation on intermediary metabolism in the rat liver. In both studies no effect of fumaric acid on the activities of enzymes in the citric-acid cycle was found. However, Tschierschwitz et al. (1982) observed increased activity of aspartate transferase (EC 2.6.1.1) and succinate dehydrogenase (EC 1.3.5.1) with the addition of fumaric acid to rat diets. Grassmann \& Klasna (1986) reported that fumarase (EC 4.2.1.2) activity in the cytosolic fraction was increased by fumaric acid supplementation. It also increased liver transaminase (glutamate dehydrogenase ( $E C$ 1.4.1.2), glutamate-oxaloacetate transaminase (EC 2.6.1) and glutamate-pyruvate transaminase) activities, which may indicate increased synthesis of nonessential amino acids.

Grassmann \& Kirchgessner (1979) and Grassmann \& Klasna (1986) measured the effects of supplementation of diets with citric-acid on intermediary metabolism in the rat liver. There was no effect of citric-acid supplementation on the activities of enzymes in the citric-acid cycle. However, succinate dehydrogenase activity was increased in one study and decreased in another. Grassmann \& Kirchgessner (1979) reported that citric-acid supplementation did not affect the activities of liver transaminases. However, Grassmann \& Klasna (1986) reported that citric-acid supplementation increased liver glutamate dehydrogenase, glutamate-oxaloacetate transaminase and glutamate-pyruvate transaminase activities. An increase in transaminase activities may indicate that the $\mathrm{C}$ skeleton of citrate is being used to synthesize nonessential amino acids.

\section{Concluding remarks and future perspectives}

Organic acids and their salts have been established as potential alternatives to prophylactic use of in-feed antibiotics in order to improve the performance of weaned piglets, fattening pigs and reproductive sows. However, their effect on performance was found often to vary and more specific studies are necessary to elucidate an explanation. Particularly with young piglets, more attention should be paid to maintaining continuous feed intake before and after weaning, and including organic acids, as it is a prerequisite of good performance. Exact modes of action of organic acids in particular sections of the gastrointestinal tract still remain unresolved in the context of inconsistencies concerning digestion and absorption of particular organic and inorganic nutrients. From a very limited number of experiments it seems that organic acids improve the apparent ileal digestibility of amino acids in growing pigs, but not in weaned piglets. More data are needed, with studies also using adult sows. So far, no information is 
available on the influences of organic acids on endogenous protein and amino acid losses and on true digestibility of feed protein and amino acids. Organic acids may also influence gut morphology, increasing villous height and therefore the absorptive capacity, which could contribute to improved protein, energy and/or mineral absorption.

\section{Acknowledgement}

Financial support for K. Partanen from The Finnish Cultural Foundations is gratefully acknowledged.

\section{References}

Abu Damir H, Scott D, Loveridge N, Buchan W \& Milne J (1991) The effects of feeding diets containing either $\mathrm{NaHCO}_{3}$ or $\mathrm{NH}_{4} \mathrm{Cl}$ on indices of bone formation and resorption and on mineral balance in the lamb. Experimental Physiology 76, 725-732.

Argenzio A (1984) Gastrointestinal motility. In Duke’s Physiology of Domestic Animals, pp. 278-289 [MJ Swenson, editor]. Ithaca, NY: Cornell University Press.

Aumaître A, Peiniau J \& Madec F (1995) Digestive adaptation after weaning and nutritional consequences in the piglet. Pig News and Information 16, 73N-79N.

Barzel US \& Jowsey J (1969) The effects of chronic acid and alkali administration on bone turnover in adult rats. Clinical Science 36, 517-524.

Baustad B (1993) Effects of formic acid on performance in growing pigs. Norwegian Journal of Agricultural Sciences 7, 61-69.

Bolduan G, Jung H, Schneider R, Block J \& Klenke B (1988a) Influence of propionic and formic acids on piglets. Journal of Animal Physiology and Animal Nutrition 59, 72-78.

Bolduan G, Jung H, Schneider R, Block J \& Klenke B (1988b) Influence of fumaric acid and propanediol formate on piglets. Journal of Animal Physiology and Animal Nutrition 59, 143-149.

Broz J \& Schulze J (1987) Efficacy of citric acid as a feed additive in early weaned piglets. Journal of Animal Physiology and Animal Nutrition 58, 215-223.

Burnell TW, Cromwell GL \& Stahly TS (1988) Effects of dried whey and copper sulfate on the growth responses to organic acid in diets for weanling pigs. Journal of Animal Science 66, 1100-1108.

Cera KR, Mahan DC, Cross RF, Reinhart GA \& Whitmoyer RE (1988) Effect of age, weaning and postweaning diet on small intestinal growth and jejunal morphology in young swine. Journal of Animal Science 66, 574-584.

Chang EB \& Rao MC (1994) Intestinal water and electrolyte transport. Mechanisms of physiological and adaptive responses. In Physiology of the Gastrointestinal Tract, 3rd ed., pp. 2027-2075 [LR Johnson, DH Alpers, J Christensen and E Jacobsen, editors]. New York: Lippencott Raven Press.

Clark WA \& Batterham ES (1989) Citric acid supplementation of creep-weaner diets. In Manipulating Pig Production II, p. 137 [JL Barnett and DP Hennesy, editors]. Werribee, Victoria, Australia: Australasian Pig Science Association.

Cole DJ A, Beal RM \& Luscombe JR (1968) The effect on performance and bacterial flora of lactic acid, propionic acid, calcium propionate and calcium acrylate in the drinking water of weaned pigs. Veterinary Record 83, 459-463.

Cranwell PD (1995) Development of the neonatal gut and enzyme systems. In The Neonatal Pig: Development and Survival, pp. 99-154 [MA Varley, editor]. Wallingford, Oxon.: CAB International.

Easter RA (1988) Acidification of diets for pigs. In Recent Advances in Animal Nutrition - 1988, pp. 61-71 [W Haresign and DJA Cole, editors]. London: Butterworths.

Eckel B, Kirchgessner M \& Roth FX (1992a) Influence of formic acid on daily weight gain, feed intake, feed conversion rate and digestibility. 1. The nutritive value of organic acids in the rearing of piglets. Journal of Animal Physiology and Animal Nutrition 67, 93-100.

Eckel B, Roth FX, Kirchgessner M \& Eidelsburger U (1992b) Influence of formic acid on concentrations of ammonia and biogenic amines in the gastrointestinal tract. 4. Nutritive value of organic acids in piglet rearing. Journal of Animal Physiology and Animal Nutrition 67, 198-205.

Edmonds MS, Izquierdo OA \& Baker DH (1985) Feed additive studies with newly weaned pigs: efficacy of supplemental copper, antibiotics and organic acids. Journal of Animal Science 60, 462-469.

Eidelsburger U, Kirchgessner M \& Roth FX (1992a) Influence of formic acid, calcium formate and sodium bicarbonate on $\mathrm{pH}$, concentration of carbonic acids and ammonia in different segments of the gastrointestinal tract. 8. Nutritive value of organic acids in piglet rearing. Journal of Animal Physiology and Animal Nutrition 68, 20-32. 
Eidelsburger U, Kirchgessner M \& Roth FX (1992b) Influence of fumaric acid, hydrochloric acid, sodium formate, tylosin and toyocerin on daily weight gain, feed conversion rate and digestibility. 11. Nutritive value of organic acids in piglet rearing. Journal of Animal Physiology and Animal Nutrition 68, 82-92.

Eidelsburger U, Kirchgessner M \& Roth FX (1992c) Influence of fumaric acid, hydrochloric acid, sodium formate, tylosin and toyocerin on acid-base status. 13. Nutritive value of organic acids in piglet rearing. Journal of Animal Physiology and Animal Nutrition 68, 165-173.

Eidelsburger U, Roth FX \& Kirchgessner M (1992d) Influence of formic acid, calcium formate and sodium bicarbonate on daily weight gain, feed intake, feed conversion rate and digestibility. 7. Nutritive value of organic acids in piglet rearing. Journal of Animal Physiology and Animal Nutrition 67, 258-267.

Eidelsburger U, Roth FX \& Kirchgessner M (1992e) Influence of formic acid, calcium formate and sodium bicarbonate on acid-base status. 9. Effect of organic acids in piglet rearing. Journal of Animal Physiology and Animal Nutrition 68, 33-42.

Falkowski JF \& Aherne FX (1984) Fumaric and citric acid as feed additives in starter pig nutrition. Journal of Animal Science 58, 935-938.

Fasshauer U \& Kienzle E (1995) Effect of citric acid, olaquindox, zinc-bacitracin and zinc oxide on precaecal digestion of crude nutrients and ileocaecal flow of minerals in minipigs. Journal of Animal Physiology and Animal Nutrition 74, 219-226.

Foegeding PM \& Busta FF (1991) Chemical food preservatives. In Disinfection, Sterilization and Preservation, pp. 802-832 [SS Block, editor]. Philadelphia, PA: Lea \& Febiger.

Frank K (1994) Measures to preserve food and feeds from bacterial damage. Übersichten zur Tierernährung 22, 149163.

Frankel WL, Zhang W, Singh A, Klurfeld DM, Don S, Sakata T, Modlin I \& Rombeau JL (1994) Mediation of the trophic effects of short-chain fatty acids on the rat jejunum and colon. Gastroenterology 106, 375-380.

Fuller R (1977) The importance of lactobacilli in maintaining normal microbial balance in the crop. British Poultry Science 18, 89-94.

Gabert VM \& Sauer WC (1994) The effects of supplementing diets for weanling pigs with organic acids. A review. Journal of Animal and Feed Sciences 3, 73-87.

Gabert VM \& Sauer WC (1995) The effect of fumaric acid and sodium fumarate supplementation to diets for weanling pigs on amino acid digestibility and volatile fatty acid concentrations in ileal digesta. Animal Feed Science and Technology 53, $243-254$.

Gabert VM, Sauer WC, Schmitz M, Ahrens F \& Mosenthin R (1995) The effect of formic acid and buffering capacity on the ileal digestibilities of amino acids and bacterial populations and metabolites in the small intestine of weanling pigs fed semipurified fish meal diets. Canadian Journal of Animal Science 75, 615-623.

Gálfi P \& Bokori J (1990) Feeding trial in pigs with a diet containing sodium $n$-butyrate. Acta Veterinaria Hungarica 38, $3-17$.

Gaskins HR \& Kelley KW (1995) Immunology and neonatal mortality. In The Neonatal Pig: Development and Survival, pp. 39-55 [MA Varley, editor]. Wallingford, Oxon.: CAB International.

Gedek B, Kirchgessner M, Eidelsburger U, Wiehler S, Bott A \& Roth FX (1992a) Influence of formic acid on the microflora in different segments of the gastrointestinal tract. 5. Nutritive value of organic acids in piglet rearing Journal of Animal Physiology and Animal Nutrition 67, 206-214.

Gedek B, Roth FX, Kirchgessner M, Wiehler S, Bott A \& Eidelsburger U (1992b) Influence of fumaric acid, hydrochloric acid, sodium formate, tylosin and toyocerin on the microflora in different segments of the gastrointestinal tract. 14. Nutritive value of organic acids in piglet rearing. Journal of Animal Physiology and Animal Nutrition 68, 209-217.

Giesting DW \& Easter RA (1985) Response of starter pigs to supplementation of corn-soybean meal diets with organic acids. Journal of Animal Science 60, 1288-1294.

Giesting DW \& Easter RA (1991) Effect of protein source and fumaric acid supplementation on apparent ileal digestibility of nutrients by young pigs. Journal of Animal Science 69, 2497-2503.

Giesting DW, Roos MA \& Easter RA (1991) Evaluation of the effect of fumaric acid and sodium bicarbonate addition on performance of starter pigs fed diets of different types. Journal of Animal Science 69, 2489-2496.

Grassmann E \& Kirchgessner M (1979) Absorption of copper from complexes with various organic acids. Zeitschrift für Tierphysiologie, Tierernährung und Futtermittelkunde 25, 125-128.

Grassmann E \& Klasna T (1986) Comparative studies on the effect of supplements of fumaric and citric acids on body composition and enzyme activities of rats differently supplied with protein. Landwirtschaftliche Forschung 39, 307319.

Grassmann E, Roth FX \& Kirchgessner M (1992) Metabolic effects of formic acid in daily use. 6. Nutritive value of organic acids in piglet rearing. Journal of Animal Physiology and Animal Nutrition 67, 250-257.

Harada E \& Kato S (1983) Effect of short-chain fatty acids on the secretory response of the ovine exocrine pancreas. American Journal of Physiology 244, G284-G290.

Harada E, Kiriyama H, Kobayashi E \& Tsuchita H (1988) Postnatal development of biliary and pancreatic exocrine secretion in piglets. Comparative Biochemistry and Physiology 91A, 43-51.

Harada E, Niiyama M \& Syuto B (1986) Comparison of pancreatic exocrine secretion via endogenous secretin by intestinal infusion of hydrochloric acid and monocarboxylic acid in anesthetized piglets. Japanese Journal of Physiology 36, 843-856. 
Hedges LV \& Olkin I (1985) Statistical Methods for Meta-Analysis. San Diego, CA: Academic Press.

Henry RW, Pickard DW \& Hughes PE (1985) Citric acid and fumaric acid as food additives for early-weaned piglets. Animal Production 40, 505-509.

Höhler D \& Pallauf J (1993) Effect of citric acid added to a maize-soya diet with or without Zn supplementation on the availability of minerals. Journal of Animal Physiology and Animal Nutrition 69, 133-142.

Höhler D \& Pallauf J (1994) Effect of Zn supply and addition of citric acid to a maize-soya diet on the nutritive value and mineral absorption in piglets. Journal of Animal Physiology and Animal Nutrition 71, 189-199.

Imoto S \& Namioka S (1983) Nutritive value of acetate in growing pigs. Journal of Animal Science 56, 858-866.

Jahn S \& Uecker E (1987) Research on the economics of enterotoxaemia due to coliforms in pigs. Monatshefte für Veterinär Medizin 42, 769-771.

Jasaitis DK, Wohlt JE \& Evans JL (1987) Influence of feed ion content on buffering capacity of ruminant feedstuffs in vitro. Journal of Dairy Science 70, 1391-1403.

Johlin FC, Fortman CS, Nghiem DD \& Tephly TR (1987) Studies on the role of folic acid and folate-dependent enzymes in human methanol poisoning. Molecular Pharmacology 31, 557-561.

Johlin FC, Swain E, Smith C \& Tephly TR (1989) Studies on mechanism of methanol poisoning: purification and comparison of rat and human liver 10-formyltetrahydrofolate dehydrogenase. Molecular Pharmacology 35, $745-$ 750.

Jongbloed AW (1987) Phosphorus in the Feeding of Pigs. Effect of the Diet on the Absorption and Retention of Phosphorus by Growing Pigs. Report no. 179. Lelystad, The Netherlands: IVVO.

Jongbloed AW \& Jongbloed R (1996) The Effect of Organic Acids in Diets for Growing Pigs on Enhancement of Microbial Phytase Efficacy. ID-DLO Report no. 96009. Lelystad, The Netherlands: Insitute for Animal Science and Health.

Jongbloed AW, Kemme PA, Mroz Z \& Mäkinen M (1995) Apparent total tract digestibility of ash and minerals in pigs as affected by phytate, microbial phytase, and lactic acid. Journal of Animal Science 73, (Suppl. 1), 188.

Kato S, Asakawa N, Mineo H \& Ushijima J (1989) Effect of short-chain fatty acids on pancreatic exocrine secretion in calves aged 2 weeks and 13 weeks. Japanese Journal of Veterinary Science 51, 1123-1127.

Kemme PA, Jongbloed AW, Mroz Z \& Mäkinen M (1995) Apparent ileal amino acid digestibility in pigs as affected by phytate, microbial phytase, and lactic acid. Journal of Animal Science 73, Suppl. 1, 173.

Kidder DE \& Manners MJ (1978) Digestion in the Pig. Bristol, Avon: Scientechnica.

Kirchgessner M, Eckel B, Roth FX \& Eidelsburger U (1992) Influence of formic acid on carcass composition and retention of nutrients. 2. Nutritive value of organic acids in piglet rearing. Journal of Animal Physiology and Animal Nutrition 67, 101-110.

Kirchgessner M, Paulicks BR \& Roth FX (1997) Effects of supplementations of diformate complexes (FormiTM LHS) on growth and carcass performance of piglets and fattening pigs in response to application time. Agribiological Research 50, 1-7.

Kirchgessner M \& Roth FX (1976) Rearing piglets on a diet containing fumaric acid. Züchtungskunde 48, 402-406.

Kirchgessner M \& Roth FX (1978a) Fumaric acid as a supplement in rearing piglets and in fattening pigs. Züchtungskunde 50, 17-25.

Kirchgessner M \& Roth FX (1978b) Effect of the addition of fumaric acid on the nutritive value and energy intake. Zeitschrift für Tierphysiologie, Tierernährung und Futtermittelkunde 42, 71-76.

Kirchgessner M \& Roth FX (1980) Digestibility and balance of protein, energy and some minerals in piglets given supplements of fumaric acid. Zeitschrift für Tierphysiologie, Tierernährung und Futtermittelkunde 44, 239-246.

Kirchgessner M \& Roth FX (1982) Propionic acid as a feed additive in the rearing of piglets and fattening of pigs. Wirtschaftseigene Futter 28, 225-234.

Kirchgessner M \& Roth FX (1987a) Use of formates in the feeding of piglets. 1. Calcium formate. Landwirtschaftliche Forschung 40, 141-152.

Kirchgessner M \& Roth FX (1987b) Use of formates in piglet nutrition. 2. Sodium formate. Landwirtschaftliche Forschung 40, 287-294.

Kirchgessner M \& Roth FX (1988) Energy value of organic acids in the rearing of piglets and the fattening of pigs. Übersichten zur Tierernährung 16, 93-108.

Kirchgessner M \& Roth FX (1989) Use of calcium formate in the fattening of pigs. Landwirtschaftliche Forschung $\mathbf{4 2}$, $150-156$.

Kirchgessner M \& Roth FX (1990) Nutritive effect of calcium formate in combination with free acids in the feeding of piglets. Agribiological Research 43, 53-64.

Kirchgessner M, Roth FX \& Eidelsburger U (1993) Nutritive value of tartaric and malic acids in piglet rearing. Journal of Animal Physiology and Animal Nutrition 70, 216-224.

Kirchgessner M, Roth FX \& Paulicks BR (1995) Nutritive value of sorbic acid in piglet rearing. Journal of Animal Physiology and Animal Nutrition 74, 235-242.

Kirchgessner M \& Roth-Maier DA (1975) The addition of citric acid to piglet rations. Züchtungskunde 47, 329-335.

Kokue E, Sekiya T, Shinoda M \& Natsuhori M (1994) Pharmacokinetics and bioavailability of folic acid and plasma levels of bioactive folates after folic acid administration to pigs. Veterinary Quarterly 16, 91-94.

Kornegay ET, Evans JL \& Ravindran V (1994) Effects of diet acidity and protein level or source of calcium on the performance, gastrointestinal content measurements, bone measurements, and carcass composition of gilts and barrow weanling pigs. Journal of Animal Science 72, 2670-2680. 
Krause DO, Harrison PC \& Easter RA (1994) Characterization of the nutritional interactions between organic acids and inorganic bases in the pig and chick. Journal of Animal Science 72, 1257-1262.

Letendre M, Girard CL, Matte JJ \& Bernier JF (1991) Effect of intramuscular injections of folic acid on folates status and growth performance of weanling pigs. Canadian Journal of Animal Science 71, 1223-1231.

Lide DR (1989-90) CRC Handbook of Chemistry and Physics, 70th ed. Boca Raton, FL: CRC Press.

Lindemann MD (1993) Supplemental folic acid: a requirement for optimizing swine reproduction. Journal of Animal Science 71, 239-246.

Littell RC, Milliken GA, Stroup WW \& Wolfinger RD (1996) SAS ${ }^{\circledR}$ System for Mixed Models. Cary, NC: SAS Institute Inc.

Lueck E (1980) Antimicrobial Food Additives: Characteristics, Uses, Effects. Berlin, Germany: Springer-Verlag.

Lupton JR \& Kurtz PP (1993) Relationship of colonic luminal short-chain fatty acids and pH to in vivo cell proliferation in rats. Journal of Nutrition 123, 1522-1530.

McDonald P, Edwards RA, Greenhalgh JFD \& Morgan CA (1995) Animal Nutrition, 5th ed. London: Longman Scientific \& Technical.

Makar AB, Tephly TR, Sahin G \& Osweiler G (1990) Formate metabolism in young swine. Toxicology and Applied Pharmacology 105, 315-320.

Maner JH, Pond WG, Loosli JK \& Lowrey RS (1962) Effect of isolated soybean protein and casein on the gastric pH and rate of passage of food residues in baby pigs. Journal of Animal Science 21, 49-52.

Marsman KE \& McBurney MI (1996) Dietary fiber and short-chain fatty acids affect cell proliferation and protein synthesis in isolated rat colonocytes. Journal of Nutrition 126, 1429-1437.

Mathew AG, Sutton AL, Scheidt AB, Forsyth DM, Patterson JA \& Kelly DT (1991) Effects of a propionic acid containing feed additive on performance and intestinal microbial fermentation of the weanling pig. In Digestive Physiology in Pigs: Proceedings of the Vth International Symposium, EAAP Publication no. 54, pp. 464-469. Wageningen, The Netherlands: Pudoc.

Maxwell FJ \& Stewart CS (1995) The microbiology of the gut and the role of probiotics. In The Neonatal Pig: Development and Survival, pp. 155-186 [MA Varley, editor]. Wallingford, Oxon.: CAB International.

Mayer EA (1994) The physiology of gastric storage and emptying. In Physiology of the Gastrointestinal Tract, 3rd ed., vol. 1, pp. 929-976 [LR Johnson, DH Alpers, J Christensen and E Jacobsen, editors]. New York: Lippencott Raven Press.

Mosenthin R, Sauer WC, Ahrens F, de Lange CFM \& Bornholdt U (1992) Effect of dietary supplements of propionic acid, siliceous earth or a combination of these on the energy, protein and amino acid digestibilities and concentrations of microbial metabolites in the digestive tract of growing pigs. Animal Feed Science and Technology 37, $245-255$.

Mroz Z, Grela ER, Krasucki W, Kies AK \& Schöner FJ (1998) Microbial phytase in combination with formic acid for reproductive sows. Journal of Animal Science 76, Suppl. 1, 177 Abstr.

Mroz Z, Jongbloed AW, Partanen K, van Diepen JThM, Kemme PA \& Kogut J (1997) Apparent digestibility of amino acids and balance of nitrogen and minerals as influenced by buffering capacity and organic acids in diets for growing swine. Journal of Animal Science 75, Suppl. 1, 185 Abstr.

Mroz Z, Jongbloed AW, Vreman K, Canh TT, van Diepen JThM, Kemme PA, Kogut J \& Aarnink AJA (1996) The Effect of Different Dietary Cation-anion Supplies on Excreta Composition and Nutrient Balance in Growing Pigs. Report no. 96.028. Lelystad, The Netherlands: Institute of Animal Science and Health.

Nabuurs MJ A (1995) Microbiological, structural and functional changes of the small intestine of pigs at weaning. Pig News and Information 16, 93N-97N.

Øverland M \& Lys $\emptyset$ A (1997) Addition of formic acid and/or formates in diets for growing-finishing pigs. 48th Annual Meeting of the EAAP, p. 6.

Pallauf J, Göttert W \& Krämer K (1988) Influence of citric acid on the digestibility of nutrients and N balance in piglets. Deutsche Tierärztliche Wochenschrift 95, 146-150.

Paulicks BR, Roth FX \& Kirchgessner M (1996) Dose effects of potassium diformate (FormiTM LHS) on the performance of growing piglets. Agribiological Research 49, 318-326.

Petersen U \& Oslage HJ (1982a) Effect of fumaric acid alone or in combination with other growth promoters in pig production. 1. Optimal dosages of fumaric acid in relation to the type of ration. Landbauforschung Völkenrode 32, $149-151$.

Petersen U \& Oslage HJ (1982b) Effect of fumaric acid alone or in combination with other growth promoters in pig production. 3. Animal performance during application and after withdrawal of either fumaric acid or a combination of growth promoters. Landbauforschung Völkenrode 32, 157-161.

Petito SL \& Evans JL (1984) Calcium status of the growing rat as affected by diet acidity from ammonium chloride, phosphate and protein. Journal of Nutrition 114, 1049-1059.

Pluske JR, Williams IH \& Aherne FX (1996) Maintenance of villous height and crypt depth in piglets by providing continuous nutrition after weaning. Animal Science 62, 131-144.

Pölönen IJ, Vahteristo LT \& Tanhuanpää EJ (1997) Effect of folic acid supplementation on folate status and formate oxidation rate in mink (Mustela vision). Journal of Animal Science 75, 1569-1574.

Radcliffe JS, Zhang Z \& Kornegay ET (1998) The effects of microbial phytase, citric acid, and their interaction in a corn-soybean meal-based diet for weanling pigs. Journal of Animal Science 76, 1880-1886.

Radecki SV, Juhl MR \& Miller ER (1988) Fumaric and citric acids as feed additives in starter pig diets: effect on performance and nutrient balance. Journal of Animal Science 66, 2598-2605. 
Ravindran V \& Kornegay ET (1993) Acidification of weaner pig diets: a review. Journal of the Science of Food and Agriculture 62, 313-322.

Risley CR, Kornegay ET, Lindemann MD \& Weakland SM (1991) Effects of organic acids with and without a microbial culture on performance and gastrointestinal tract measurements of weanling pigs. Animal Feed Science and Technology 35, 259-270.

Risley CR, Kornegay ET, Lindemann MD, Wood CM \& Eigel WN (1992) Effect of feeding organic acids on selected intestinal content measurements at varying times postweaning in pigs. Journal of Animal Science 70, 196-206.

Risley CR, Kornegay ET, Lindemann MD, Wood CM \& Eigel WN (1993) Effect of feeding organic acids on gastrointestinal digesta measurements at various times postweaning in pigs challenged with enterotoxigenic Escherichia coli. Canadian Journal of Animal Science 73, 931-940.

Roth FX, Eckel B, Kirchgessner M \& Eidelsburger U (1992a) Influence of formic acid on pH, dry matter content, and concentrations of volatile fatty acids and lactic acid in the gastrointestinal tract. 3. Nutritive value of organic acids in piglet rearing. Journal of Animal Physiology and Animal Nutrition 67, 148-156.

Roth FX, Eidelsburger U \& Kirchgessner M (1992b) Influence of fumaric acid, hydrochloric acid, sodium formate, tylosin and toyocerin on $\mathrm{pH}$, dry matter content, concentration of carbonic acids and ammonia in different segments of the gastrointestinal tract. 12. Nutritive value of organic acids in piglet rearing. Journal of Animal Physiology and Animal Nutrition 68, $93-103$.

Roth FX \& Kirchgessner M (1982) The nutritive value of Ca propionate in diets for piglets and fattening pigs. Wirtschaftseigene Futter 28, 235-242.

Roth FX \& Kirchgessner M (1988) Use of acetic acid in pig nutrition. Landwirtschaftliche Forschung 41, $253-258$.

Roth FX \& Kirchgessner M (1989) Significance of dietary $\mathrm{pH}$ and buffering capacity in piglet nutrition. 1. pH and buffering capacity in diets supplemented with organic acids. Landwirtschaftliche Forschung 42, 157-167.

Roth FX, Kirchgessner M \& Eidelsburger U (1993) Nutritive value of lactic acid in piglet rearing. Agribiological Research 46, 229-239.

Roth FX, Kirchgessner M \& Paulicks BR (1996) Nutritive use of feed additives based on diformates in the rearing and fattening of pigs and their effects on performance. Agribiological Research 49, 307-317.

Sakata T (1987) Stimulatory effect of short-chain fatty acids on epithelial cell proliferation in the rat intestine: a possible explanation for trophic effects of fermentable fibre, gut microbes and luminal trophic factors. British Journal of Nutrition 58, 95-103.

Sakata T, Adachi M, Hashida M, Sato N \& Kojima T (1995) Effect of $n$-butyric acid on epithelial cell proliferation of pig colonic mucosa in short-term culture. Deutsche Tierärztliche Wochenschrift 102, 163-164.

Sano H, Nakamaura E, Takahashi H \& Terashima Y (1995) Plasma insulin and glucagon responses to acute challenges of acetate, propionate, $n$-butyrate and glucose in growing gilts (Sus scrofa). Comparative Biochemistry and Physiology 110A, 375-378.

Schulz E \& Fischer F-W (1983) Use of different kinds of acidified skim milk in the fattening of pigs. Landbauforschung Völkenrode 33, 22-26.

Schulz E \& Oslage HJ (1982) Effect of fumaric acid alone or in combination with other growth promoters in pig production. 2. Combined effect of fumaric acid and antibiotics (Avoparsin). Landbauforschung Völkenrode 32, $152-156$.

Scipioni R, Zaghini G \& Biavati B (1978) The use of acidified diets for early weaning of piglets. Zootecnica $e$ Nutrizione Animale 4, 201-218.

Smith HW \& Jones JET (1963) Observations on the alimentary tract and its bacterial flora in healthy and diseased pigs. Journal of Pathology and Bacteriology 86, 387-412.

Solomon TE (1994) Control of exocrine pancreatic secretion. In Physiology of the Gastrointestinal Tract, 3rd ed. vol. 2, pp. 929-976 [LR Johnson, DH Alpers, J Christensen and E Jacobsen, editors]. New York: Lippencott Raven Press.

Straw ML, Kornegay ET, Evans JL \& Wood CM (1991) Effects of dietary pH and phosphorus source on performance, gastrointestinal tract digesta, and bone measurements of weanling pigs. Journal of Animal Science 69, 4496-4504. Stryer L (1988) Biochemistry, 3rd ed. New York: WH Freeman and Company.

Tephly TR (1991) The toxicity of methanol. Life Sciences 48, 1031-1041.

Thacker PA \& Bowland JP (1980) Influence of graded levels of dietary propionic acid on performance and carcass traits of swine fed diets supplemented with soybean meal or canola meal. Canadian Journal of Animal Science 60, $971-$ 978.

Thacker PA \& Bowland JP (1981) Effects of vitamin $B_{12}$ on performance and carcass traits of pigs fed diets supplemented with propionic acid or calcium propionate. Canadian Journal of Animal Science 61, 775-782.

Thacker PA, Campbell GL \& Groot Wassink J (1992) The effect of organic acids and enzyme supplementation on the performance of pigs fed barley-based diets. Canadian Journal of Animal Science 72, 395-402.

Thacker PA, Salomons MO, Aherne FX, Milligan LP \& Bowland JP (1981) Influence of propionic acid on the cholesterol metabolism of pigs fed hypercholesterolemic diets. Canadian Journal of Animal Science 61, 969-975.

Thomlinson JR \& Lawrence TLJ (1981) Dietary manipulation of gastric pH in the prophylaxis of enteric disease in weaned pigs: Some field observations. Veterinary Record 109, 120-122.

Tschierschwitz A, Grassmann E, Kirchgessner M \& Roth FX (1982) The effect of fumaric acid supplements on activities of liver enzymes (GOT, GPT, SUCCDH) with different supplies of energy and protein to growing rats. Zeitschrift für Tierphysiologie, Tierernährung und Futtermittelkunde 48, 253-259. 
Weeden TL, Nelssen JL, Hansen JA \& Richardson KL (1991) The effect of diet acidification on starter performance and nutrient digestibility. Journal of Animal Science 69, Suppl. 1, 105-106.

Wohlt JE, Jasaitis DK \& Evans JL (1987) Use of acid and base titrations to evaluate the buffering capacity of ruminant feedstuffs in vitro. Journal of Dairy Science 70, 1465-1470.

Wolffram S, Bisang B, Grenacher B \& Scharrer E (1990) Transport of tri- and dicarboxylic acids across the intestinal brush border membrane of calves. Journal of Nutrition 120, 767-774.

Wolffram S, Hagemann C, Grenacher B \& Scharrer E (1992) Characterization of the transport of tri- and dicarboxylates by pig intestinal brush-border membrane vesicles. Comparative Biochemistry and Physiology 101A, 759-767.

Zhang J, Pettigrew JE, Chester-Jones H, Cornelius SG \& Moser RL (1986) Efficacy of sodium diacetate as a growth promotant for swine. Nutrition Reports International 33, 893-898.

(C) Nutrition Society 1999 